DOE/ID/12009--T2

DE82 021852

GEOTHERMAL-RESOURCE POTENTIAL

FOR A PORTION OF THE

SAN PEDRO RIVER VALLEY

\title{
$\therefore \quad$ BOTICE
}

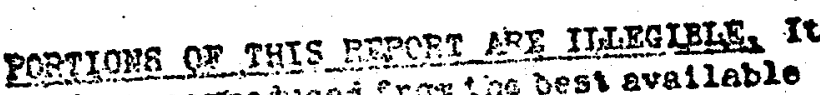

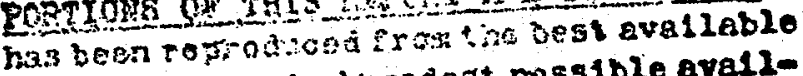
oopy to parait the broedest possible avaliab1115\%.

by

W. Richard Hahman, Sr. Geothermal Group Geological Survey Branch

Bureau of Geology and Mineral Technology

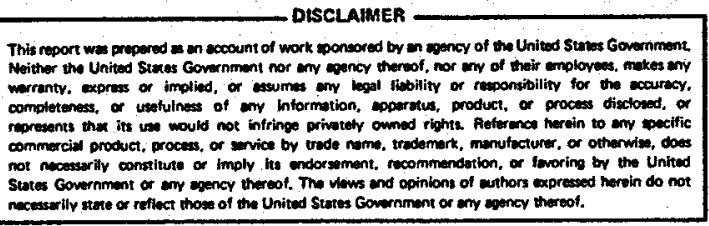




\section{DISCLAIMER}

This report was prepared as an account of work sponsored by an agency of the United States Government. Neither the United States Government nor any agency Thereof, nor any of their employees, makes any warranty, express or implied, or assumes any legal liability or responsibility for the accuracy, completeness, or usefulness of any information, apparatus, product, or process disclosed, or represents that its use would not infringe privately owned rights. Reference herein to any specific commercial product, process, or service by trade name, trademark, manufacturer, or otherwise does not necessarily constitute or imply its endorsement, recommendation, or favoring by the United States Government or any agency thereof. The views and opinions of authors expressed herein do not necessarily state or reflect those of the United States Government or any agency thereof. 


\section{DISCLAIMER}

Portions of this document may be illegible in electronic image products. Images are produced from the best available original document. 


\section{RECONNAISSANCE STUDY \\ GEOTHERMAI RESOURCE POTENTIAL OF A PORTION \\ OF THE SAN PEDRO RIVER VALLEY}

\section{INTRODUCTION}

A preliminary investigation of the geothermal resource potential of the san pedro River valley was undertaken the latter part of 1980 . The area of investigation is situated in Pinal, Pima and Cochise counties, Arizona. It extends from the town of Mammoth, Pinal county, south-southeast along the river valley to just north of the Johnny Lyon Hills, an area comprising $2331 \mathrm{~km}^{2}\left(900 \mathrm{mi}^{2}\right)$.

With the exception of mining and smelting activities In the Mammoth-san Manuel area, the primary business in the valley is agriculture, cattle ranching and forage crops. The majority of the irrigation, livestock, and domestic wells are along the bed of the San pedro River, an ephemeral stream that flows northward from its headwaters in Mexico. The wells generally vary in depth from $24 \mathrm{~m}(80 \mathrm{ft})$ to $36 \mathrm{~m}(120 \mathrm{ft})$ and essentially produce from the subsurface river flow.

In the Mammoth-san Manuel area there are some warm artesian wells that vary in depth from approximately $244 \mathrm{~m}$ $(800 \mathrm{ft})$ to $457 \mathrm{~m}(1500 \mathrm{ft})$. The warmest temperature measured in these wells was $40^{\circ} \mathrm{C}\left(104^{\circ} \mathrm{F}\right)$. 
GENERAL GEOLOGY

The San Pedro River valley lies along the western edge of the Mexican Highland section of the Basin and Range province (Fenneman, 1931). Fenneman (1931) describes this section of the Basin and Range province as "approximately half mountain and half plain" with a northwestward trend. In this report the studied portion of the san pedro River valley is bounded on the west by the santa Catalina and Rincon mountains and on the east by the raliuro and winchester mountains. Figure 1 is the regional geology of the study area compiled from the Geologic Map of Arizona (1969) by Wilson, Moore and Cooper.

Both Heinal (1963) in the Mammoth-San Manuel area and Montgomery (1963) in the Tres Alamos wash (just south of the Johnny Iyon Hills) area show the San Pedro River valley to be a complex graben structure trending approximately N. $30^{\circ} \mathrm{W}$. This graben structure is step-faulted downward toward the center of the basin from the eastern and western bounding mountain ranges.

The high angle normal faulting commenced approximately $15 \mathrm{~m} \cdot \mathrm{y} \cdot$ ago at the advent of the Basin and Range disturbance (Shafiqullah and others, 1980 ) during midale to late Miocene. The major faulting that formed the graben in the san pedro River valley had probably concluded by midale to late pliocene with only minor structural adjustments since that time. 

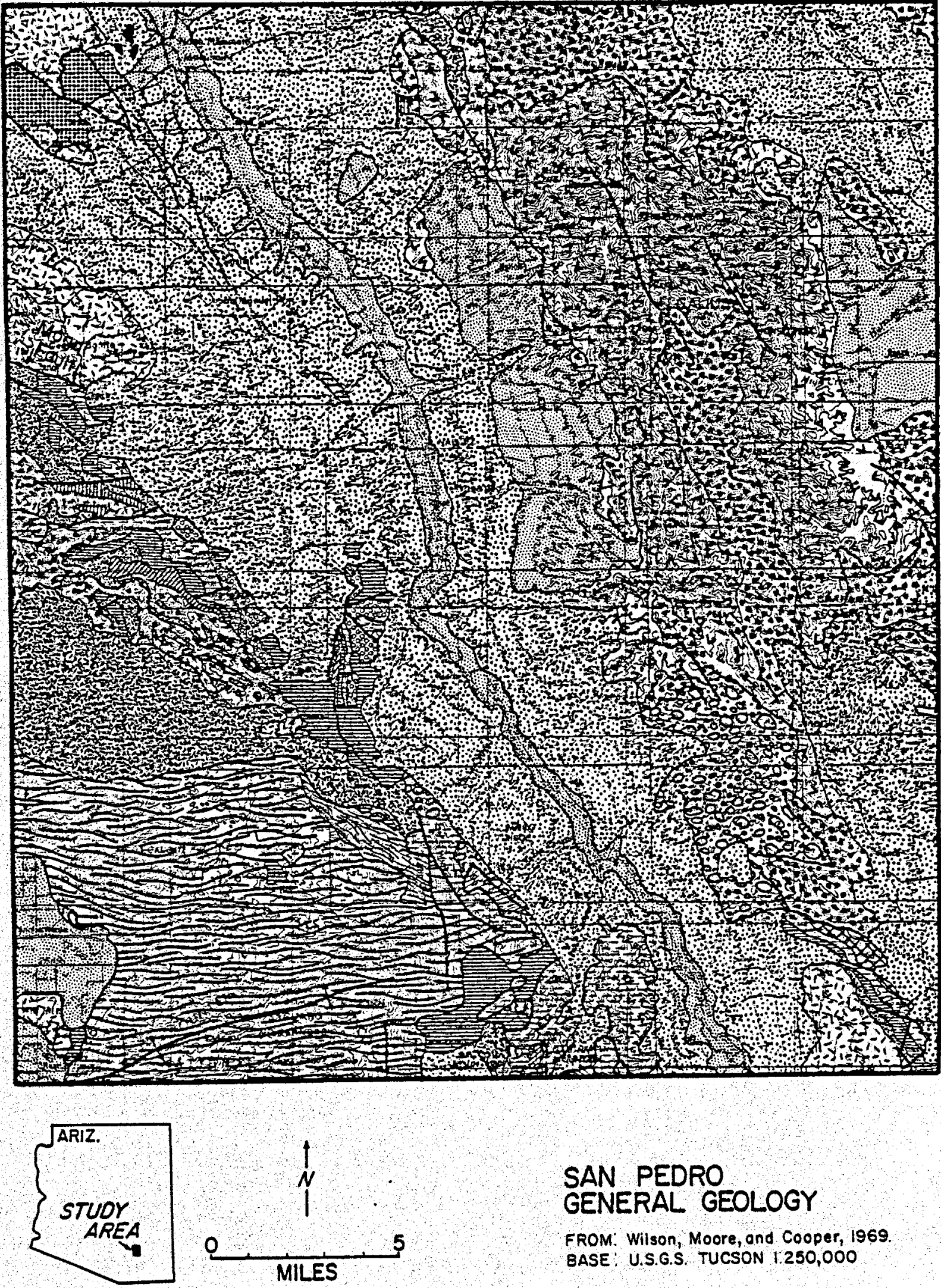

\section{SAN PEDRO GENERAL GEOLOGY}

FROM: Wilson, Moore, ond Cooper, 1969.

BASE U.S.G.S TUCSON 1.250,000

Figure 1 
9 Qs: Sedimentary deposits

1 OTs: Sedimentary deposits

50.0 Tms. Sedimentary rocks

Ti: Dikes, sills, and plugs

90 Tvi: Intermediate volcanics

[.] Trs. Silicic volcanics

TKs: Sedimentary rocks

$\because$ TKdi: Diorite

TKg: Granite

$\rightleftharpoons$ TKgn: Gneiss

[11III] TKsc. Schist

Ks: Sedimentary rocks

$\rightarrow$ Kv Volcanic rocks

\section{In⿴囗十) Ka: Andesite}

E. Kvs: Sedimentary and volcanic rocks

$\because$ Pnu: Upper formations

PPnl: Lower formations

\%ా: PPn: Naco Group

MDs: Sedimentary rocks

OEs: Sedimentary rocks

pedb: Diabase

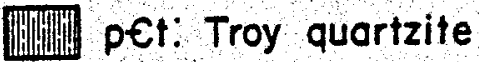

p.a. Apache group

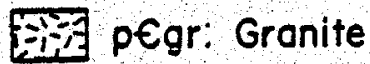

pesc: Schist

pegn: Gneiss

Explanation for Figure ।.

Figure 2 
Scarborough (1975) postulated a doming of the san Pedro basin in late pliocene time that, coupled with the steady downcutting of the san Pedro River, has left the Pliocene and Pleistocene sedimentary deposits at elevations higher than would normally be expected. The apparent absence of post-pliocene faulting (Menges, 1981) tends to give credence to the doming hypothesis.

Figure 3 is a simplified stratigraphic column of the Cenozoic lithologies present in the area of investigation (Menges, pers. commun., 1981). The thicknesses of these units vary throughout the san pedro valley. The brief descriptions of the lithologic units were synthesized from Heinal (1963); Montgomery (1963); Krieger (1974); Krieger et a1., (1974), and scarborough and wilt (1979). The reader is referred to these writers for more detailed descriptions and for an understanding of the magnitude of the correlation problem.

The pre-Cenozoic stratigraphy (Fig. 4) crops out on the west side of the valley and along the east flanks of the santa catalina Mountains. The majority of the study area was mapped by Cunningham and Hahman in 1963. The west-northwest-trending Mogul fault plays a key role in the geology of the san pearo kiver valley in the area of investigation. The Mogul fault appears to be part of the Texas zone (Rehrig and Heidrick, 1976). For a dis- 
CENOZOIC

STRATIGRAPHIC COLUMN

SAN PEDRO RIVER VAILEY

STUDY AREA

\begin{tabular}{|c|c|c|}
\hline Formation Name & $Y$ Is $\times 10^{6}$ & Description \\
\hline Unnamed gravels & $\leq 2$ & $\begin{array}{l}\text { Pleistocene and Recent: river gravels } \\
\text { and alluvial fan deposits (possibly the } \\
\text { informal Tres Alamos Fm of Montgomery, } \\
\text { 1963). }\end{array}$ \\
\hline Quiburus Fm & $4-7$ & $\begin{array}{l}\text { Pliocene: flne-grained lacustrine } \\
\text { deposits with some fluvial deposits in } \\
\text { places overlain by unnamed Pleistocene } \\
\text { gravels and alluvial fans. The main } \\
\text { sedimentary unit exposed in the river } \\
\text { valley in the area of study. }\end{array}$ \\
\hline Galiuro volcanic & $22-29$ & $\begin{array}{l}\text { Ollgocene and Mlocene: rhyolite to } \\
\text { andesite lava flows and ash flow tuffs. }\end{array}$ \\
\hline "Teran" beds & $\geq 27$ & $\begin{array}{l}\text { Oligocene, fanglomerates, sandstone, } \\
\text { shale and mudstone with a centrally } \\
\text { sltuated andesite }\end{array}$ \\
\hline
\end{tabular}

Figure 3 
PRE-CENOZOIC

STRATIGRAPHIC COLUMN

SAN PEDRO RIVER VALLEY

STUDY AREA

\begin{tabular}{|c|c|c|c|}
\hline ERA & PERIOD \& FORMATION & & YRS $\times 10^{6}$ \\
\hline Cenozolc & See F1gure 2 & unconformity & \\
\hline Mesozolc & $\begin{array}{l}\text { undifferentiated } \\
\text { volcantc rocks } \\
\text { arkoses } \\
\text { red beds }\end{array}$ & unconformity & 65 \\
\hline \multirow{5}{*}{ Paleozolc } & $\begin{array}{l}\text { Pennsylvanian Hor- } \\
\text { quilla Ls }\end{array}$ & unconformity & $\begin{array}{l}247 \\
341\end{array}$ \\
\hline & $\begin{array}{l}\text { Mississtppian } \\
\text { Escabrosa Ls }\end{array}$ & unconformity & 367 \\
\hline & Devonian Martin Fm & unconformity & 416 \\
\hline & $\begin{array}{l}\text { S1lurian } \\
\text { Ordovician missing }\end{array}$ & unconformity & 510 \\
\hline & $\begin{array}{l}\text { Cambrian } \\
\text { Abrigo Fm } \\
\text { Bolsa Quartzite }\end{array}$ & unconformity & 570 \\
\hline $\begin{array}{r}\text { Precambrian } \\
\text { younger }\end{array}$ & $\begin{array}{l}\text { Troy Quartzite } \\
\text { Mescal IImestone } \\
\text { Dripplng Springs Qtzite }\end{array}$ & unconformity & 1420 \\
\hline older & Oracle granite & & \\
\hline
\end{tabular}

\section{Figure 4}


cussion of the Texas zone or lineament the reader is referred to Schmitt (1966); Swan (1976); and Titley (1976). For a discussion of the Mogul fault and the regional geology affecting the San pedro River valley the reader is referred to Durning and Davis (1978), Silver (1978); and Drewes and Thorman (1978).

The Mogul fault, a left-lateral, normal fault, is situated at the northern end of the Catalina Mountains and south of oracle. It strikes approximately $\mathrm{N} .70^{\circ} \mathrm{w}$. and dips steeply to the southwest. Durning and Davis (1976) indicated a dip of $55^{\circ} \mathrm{sw}$, a heave or horizontal displacement component of $1500 \mathrm{ft}$, and a minimum throw or vertical displacement component of $4500 \mathrm{ft}$.

Drewes and Thoman (1978, Fig. 1) appeared to correlate the Mogul fault in the northern end of the study area with Cooper's (1958) Antelope Tank fault, which passes north of the Johnny Lyon Hills and south of the Teran basin in the southern end of the study area. This apparent correlation seems tenuous. Drewes and Thomman (1978) indicated that both faults have the same relative movements. However, Cooper (1958) and Durning and Davis (1978) indicated the relative movements on the two faults are opposite to each other. Projections of their strikes on the USGS $2^{\circ}$ Tucson map indicate that the faults are probably parallel to each other. Examination of the current magnetic (Sauck and sum- 
ner, 1971) and gravity (Lysonski, Aiken and Sumner, 1981) (Fig. 5) data do not indicate any physical connection of the two faults under the valley fill. The gravity and magnetic data indicate the projected traces of the two faults are obscured by the east and west basin bounding faults and the Morenci lineament, as well as by the Galiuro volcanic rocks in the basin. The Antelope Tank fault is projected northwestward into the vicinity of Hookers Hot Springs where it is apparently obscured by the oligocene-Miocene Galiuro volcanic rocks and the Morenci lineament.

The vertical movement on the Mogul fault has apparently controlled preservation of the paleozoic lithologies in the San Pedro River valley (Titley, 1976). On the north-northeast (upthrown) block the Paleozoic section is not preserved. Where the Precambrian rocks are exposed, they are in contact with and overlain by Mesozoic and Cenozoic (?) rocks. on the downthrown block the paleozoic section is preserved on the east side of the catalina Mountains. East of the study area in the winchester Mountains, on the north side of the downthrown Antelope Tank fault, Paleozoic sediments are observed deposited on Precambrian basement rocks. Therefore, the Mogul and Antelope Tank faults do not appear to be the same fault.

The gravity and magnetic data indicate the Black Hills, a Paleozoic outcrop south of San Manuel and north of the projected southeast extension of the Mogul fault, to be root- 



Figure 5 
less. Therefore, the Black Hills are inferred to be a slide block from the catalina Mountains rather than a small horst in a complex graben.

To further complicate the geological picture, the Morenci lineament (Fig. 5) passes through the san pedro valley in a northeast-southwest direction (Chapin et al., 1978, and witcher, pers. commun., 1981). The lineament, approximately 8 to $12 \mathrm{~km}(5$ to $8 \mathrm{mi})$ wide in the study area, passes through the Galiuro Mountains just to the north of Hookers Hot springs, the southern edge being reflected in the "dog leg" to the southwest along pine Ridge and Rockhouse Canyon, T. 12 S,, R. 21 E. In the Galiuro Mountains the Morenci lineament passes south of Bassett peak, the northern boundary being in the vicinity of the west-trending portion of Redfield Canyon. In the basin, the lineament passes south of Redington and north of Cascabel exiting the valley in the vicinity of Piety Hill and Mineta Ridge. The lineament zone passes through Redington pass, which divides the northern Santa Catalina Mountains from the southern Rincon Mountains, and could well account for the southwestward extension of the northern Rincon Mountains.

Witcher (1981) describes the Morenci lineament in Arizona as follows:

(1) The San Francisco River changes direction near 
Glenwood and follows the lineament.

(2) The Gila River changes course south of clifton and follows the lineament through the peloncil1o Mountains.

" (3) Nearly every mountain range and basin show a "dog leg" at the lineament intersections in southeastern Arizona.

(4) Every other mountain block is structurally high--three of four of these blocks are metamorphic core complexes (Davis and Coney, 1979), with the easternmost in Arizona.

(5) Sediment-filled basins traversed by the Morenci lineament have the lowest and most intense residual Bouguer gravity anomalies in southeastern Arizona (Iysonski and others, 1980). These anomalles are on or immediately adjacent to the lineament. The anomalies are interpreted to indicate that these basins have the greatest thicknesses of basin-filling sediments, which may signify the greatest structural displacements.

" (6) Every hot spring with a temperature greater than $40^{\circ} \mathrm{C}$ in southeastern Arizona occurs within 19 lateral kilometers of this lineament. sixty percent of all reported warm and hot springs $\left(>30^{\circ} \mathrm{C}\right)$ in Arizona occur within 48 kilometers 
of this lineament (see Fig. 3 of witcher).

(7) An inferred, northeast-striking structural zone crosses the Tucson area on trace of the Morenci lineament. Gravity and resistivity data suggest a fault on the north side of the Sierrita Mountains (Vroman, 1976; Davis, 1971). En echelon faults are observed along the northeast-trending Black Mountain (Percious, 1968). An aeromagnetic anomaly follows the same trend across the Tucson basin (Sauck and others, 1971). A groundwater "fall" also occurs along this trend in the rucson basin and suggests an impermeable fault boundary (Davidson, 1973). All of these features are on strike with one another.

( (8) Three different clusters of major Laramide copper deposits occur within 24 kilometers of the Morenci trend where it transects linear discontinuities of the Texas zone; they are the Pima Mining District, Safford Mining District, and the Morenci Mining District."

The intersection of the Morenci lineament with the Antelope Tank fault zone and/or the basin graben faults are postulated to provide the structural origin of Hookers Hot Springs. 
In the san pedro valley the gravity data indicate that the basin has been fillea with oligocene-Miocene Galiuro volcanic rocks. This thick sequence of volcanic rocks was downfaulted and probably simultaneously filled the basin graben structure during its formation.

A minimum depth to the Precambrian basement, north of the projected trace of the Mogul fault, may be estimated by calculating the combined thicknesses of the Quiburus Formation and the Galiuro volcanic pile assuming there are no older Cenozoic formations under the Galiuro volcanic rocks and that the paleozoic section is no longer preserved on the northern side of the Mogul fault. Heindl (1963) postulated a thickness $518 \mathrm{~m}(1700 \mathrm{ft})$ of Quiburus Formation in the Mammoth-san Manuel area. Hahman, this report, estimated a minimum thickness of $1070 \mathrm{~m}(3500 \mathrm{ft})$ of exposed Galiuro volcanic rocks, giving a minimum depth to the precambrian basement of at least $1.5 \mathrm{~km}(5200 \mathrm{ft})$.

\section{GEOTHERMAL RESOURCE}

In the latter part of 1980 a geological reconnaissance to determine the geothermal potential of a portion of the san pedro River valley was undertaken. The study area extends from the town of Mammoth, pinal county, to just north of the Johnny Lyon Hills in Cochise county. In addition to a study of the pre-existing literature, a reconnaissance field study was conducted during which 16 water samples and 
17 mercury soil samples, covering over 80 line $\mathrm{km}$, were collected. The investigation of Hookers Hot Springs was conducted by geologist Jim witcher as part of his study and evaluation of the warm and hot springs of Arizona.

The water-sampling program was unsatisfactory because of analytical errors in the water analyses from two different laboratories. partial analyses are reported for these samples, four of which are duplicates (Tables 1 and 2). Current U. S. Geological Survey WATSTORE data have been used to define the chemical regime of the water. While the writer has some confidence in the results reported as partial analyses, he has elected not to combine his data with the U.S.G.S. WATSTORE data because of the element of doubt that exists with the results of his survey.

In looking at the WATSTORE data, the San Pedro area was defined by latitudes $32^{\circ} 10^{\prime}$ to $32^{\circ} 45^{\prime} \mathrm{N}$. and longitude $110^{\circ} 10^{\prime}$ to $110^{\circ} 45^{\prime} \mathrm{W}$. This area includes the far eastern portion of Tucson, the northern part of the Rincon Mountains, the eastern half of the Santa Catalina Mountains and the southern three-quarters of the Galiuro Mountains as well as the San Pedro River valley in the study area. In this large area there are 76 chemical analyses six of which are from wells in the Tucson Basin. Where there is more than one analysis for a well, the most recent analysis was used. Not all the analyses have recorded temperatures and not all are complete. However, there is more than 
TABLE 1

SAN PEDRO RIVER VALLEY STUDY

Partial Chemlcal Analyses

Water Samples

\begin{tabular}{|c|c|c|c|c|c|c|c|c|c|c|c|c|c|c|}
\hline $\begin{array}{l}\text { Samp le } \\
\text { number }\end{array}$ & $\mathrm{mg} / 1$ & $\mathrm{mg} / 1$ & $\mathrm{ppm}$ & $\begin{array}{r}\mathrm{ppm} \\
\mathrm{Li}\end{array}$ & $\begin{array}{c}\mathrm{mg} / 1 \\
\mathrm{Na}\end{array}$ & $\underset{\mathrm{Cl}}{\mathrm{mg} / 1}$ & $\mathrm{Ppm}$ & $\mathrm{mg} / 1$ & $\begin{array}{r}\mathrm{mg} / 1 \\
\mathrm{CO}_{3}\end{array}$ & $\begin{array}{l}\mathrm{mg} / 1 \\
\mathrm{HCO}\end{array}$ & $\begin{array}{c}\mathrm{mg} / \mathrm{l} \\
\mathrm{SO}_{4}\end{array}$ & $\mathrm{mg} / 1$ & $\begin{array}{l}\text { ppm } \\
\text { TDS }\end{array}$ & pH \\
\hline sp-1 & 70 & 11.8 & 3.1 & 0.04 & 39 & 16 & 0.14 & 4.2 & 0 & 251 & 42 & 0.77 & 434 & 7.65 \\
\hline Sp-2 & 82 & 15 & 4.0 & 0.06 & 59 & 16 & 0.19 & 0.5 & 0 & 307 & 96 & 1.15 & 575 & 7.60 \\
\hline $\mathrm{Sp}-3$ & 95 & 17 & 4.26 & 0.07 & 64 & 30 & 0.21 & 0.5 & 0 & 312 & 132 & 1.15 & 650 & 7.45 \\
\hline $\mathrm{Sp}-4$ & 94 & 13.6 & 3.77 & 0.04 & 52 & 18 & 0.20 & 0.75 & 0.75 & 273 & 113 & 1.0 & 564 & 7.60 \\
\hline $\mathrm{Sp}-5$ & 66 & 9 & 4.27 & 0.12 & 46 & 18 & 0.15 & 0.5 & 0 & 278 & 72 & 0.9 & 489 & 7.50 \\
\hline $\mathrm{Sp}-6$ & 12 & 0.59 & 2.92 & 0.22 & 98 & 34 & 0.19 & 0.4 & 4.8 & 117 & 96. & 4.2 & 362 & 8.2 \\
\hline $\mathrm{Sp}-7$ & 13 & 0.58 & 2.78 & 0.22 & 96 & 34 & 0.19 & 0.4 & 4.8 & 112 & 98 & 4.22 & 358 & 8.2 \\
\hline$S p-8$ & 17 & 0.47 & 1.73 & 0.23 & 128 & 49 & 0.26 & 0.45 & 3.6 & 105 & 150 & 4.55 & 453 & 8.1 \\
\hline $\mathrm{Sp}-\mathrm{g}$ & 4.4 & 0.3 & 1.98 & 0.21 & 71 & 10 & 0.14 & 0.5 & 9.6 & 146 & 15 & 3.85 & 256 & 8.5 \\
\hline
\end{tabular}


TABLE 2

SAN PEDRO RIVER VALLEY STUDY

Partial Chemical Analyses

Water Samples

\begin{tabular}{|c|c|c|c|c|c|c|c|}
\hline & $S P-10$ & 11 & 12 & 13 & 14 & 15 & 16 \\
\hline Lithium & 0.18 & 0.26 & 0.16 & 0.17 & 0.15 & 0.10 & $<0.01$ \\
\hline Chloride & 31 & 35 & 28 & 31 & 9 & 11 & 13 \\
\hline Boron & $<0.01$ & $<0.01$ & $<0.01$ & $<0.01$ & $<0.01$ & $<0.01$ & $<0.01$ \\
\hline $\mathrm{SHO}_{2}$ & 29 & 50 & 32 & 29 & 30 & 25 & 4 \\
\hline Sulfate & 95 & 195 & 82 & 73 & 19 & 38 & 22 \\
\hline Fluoride & 1.98 & 7.05 & 6 & 5 & 6.98 & 2.60 & 1.05 \\
\hline pll & 7.94 & 7.54 & 8.38 & 8.51 & 8.77 & 7.87 & 7.28 \\
\hline
\end{tabular}


enough data to characterize the water in the San Pedro River valley.

Gradients where data were available were calculated using the following formula:

gradient $=\frac{\text { well temperature }- \text { mean annual temperature }}{\text { depth }} \times 1000$ The gradients are in ${ }^{\circ} \mathrm{C} / \mathrm{km}$.

The Na-K-Ca geothermometers were calculated using the formula of Fournier and Truesdell (1973).

$$
\begin{aligned}
t^{\circ} \mathrm{C}=\frac{1647}{\log (\mathrm{Na} / \mathrm{K})}+\beta & \log (\mathrm{Ca} / \mathrm{Na})+2.24 \\
\beta & =4 / 3 \text { if } \mathrm{T}<100^{\circ} \mathrm{C} \\
B & =1 / 3 \text { if } \mathrm{T}>100^{\circ} \mathrm{C}
\end{aligned}
$$

The silica geothermometers were calculated açcording to Fournier and Rowe (1966). The chalcedony geothermometer was used because of the greater tendency for correlation with the known reservoir temperatures in southern Arizona, the Na-K-Ca geothermometer, and the geology of the area of investigation.

Both the $\mathrm{SiO}_{2}$ and $\mathrm{Na}-\mathrm{K}-\mathrm{Ca}$ geothermometers were developed to estimate reservoir temperatures for high-temperature $\left(>150^{\circ} \mathrm{C}\right)$ geothermal resources. The geothermometers are not accurate when dealing with low- to moderate-temperature resources in a sedimentary alluvial basin. It is quite probable that numerous chemical reactions take place as the water migrates through the diverse lithologies that occur 
in the basins. Hence the results of the geothermometers should only be considered a very rough approximation and may be too high or too low. Table 3 is the compilation of the results of the $\mathrm{SiO}_{2}$ and $\mathrm{Na}-\mathrm{K}-\mathrm{Ca}$ geothermometers from the sixteen samples collected in the san pedro River valley. The Na-K-Ca results are reported from analyses from one laboratory and the $\mathrm{SiO}_{2}$ analyses are reported from analyses from another laboratory.

Table 4 is the chemical analyses from the WATSTORE file for wells in the area of interest. Record 61 is from one of the springs at Hookers Hot springs. Records 43,44 , 45, 46, 64 and 65 are from the far east side of Tucson. Table 5 is the geothermometer and geothermal gradient values calculated from the WATSTORE data. In calculating the gradient a mean annual air temperature of $18^{\circ} \mathrm{C}$ (Witcher, 1981) was used. Those gradients followed by an asterisk are calculated from wells less than $91.4 \mathrm{~m}(300 \mathrm{ft})$ deep. Figure 6 is a computer plot of the geothermal gradients in the San Pedro River valley and Fig. 7 is a computer contoured map of the gradients. The program for contouring averages the points in a given area. Thus there is less of a tendency for the computer to generate a series of "bulls eyes" around high points. The only real drawback to this approach is that some of the higher data points might not be reflected in the contouring if they are surrounded by lower values and are thereby averaged downward. 
TABLE 3

\section{GEOTHERMOMETERS}

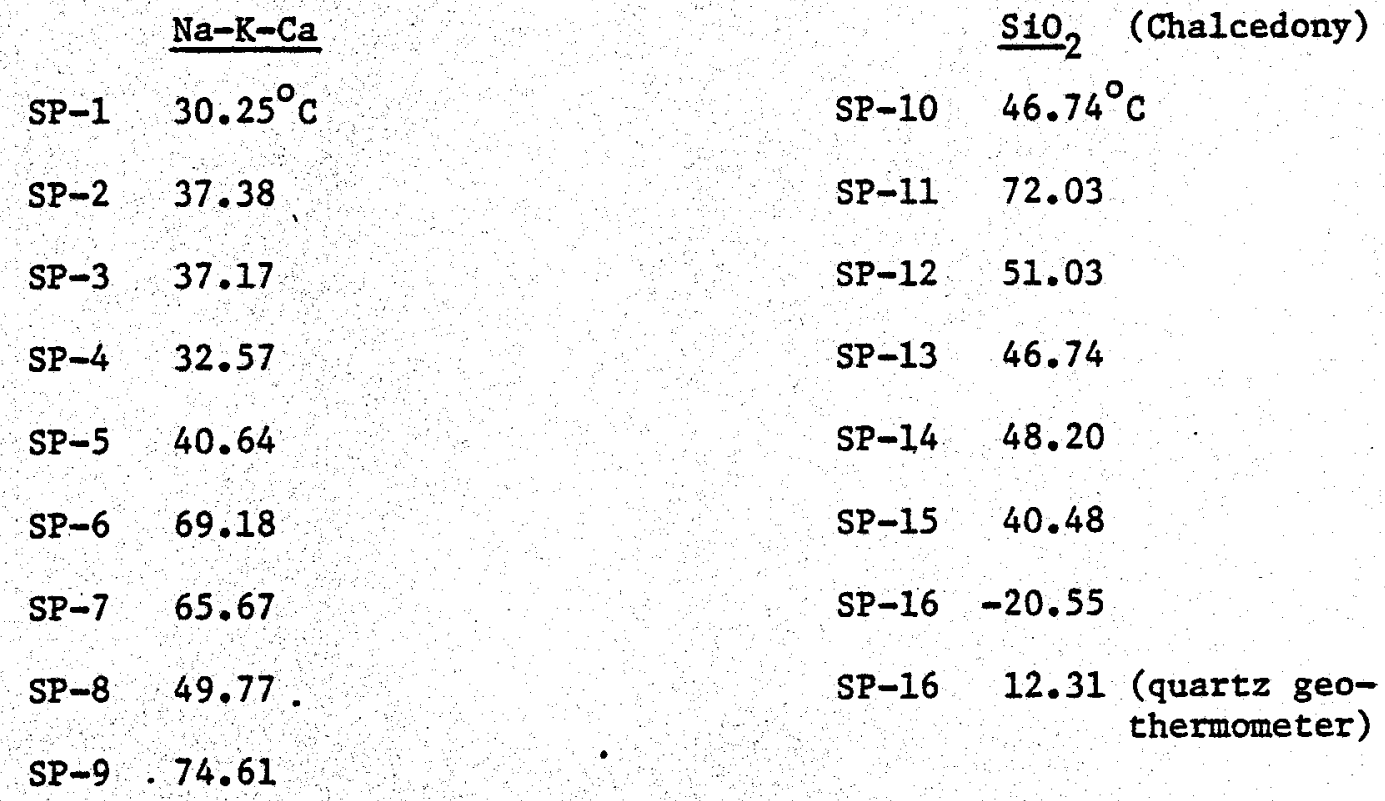

Explanation

1. Na-K-Ca calculated with $B=4 / 3$ and no magnestum correction was necessary.

2. Sample SP-10 1s a duplicate of sample SP-8. Sample SP-12 is a duplicate of sample SP-7. Sample SP-13 is a duplicate of sample SP-6. Sample SP-14 is a duplicate of sample SP-9.

3. SP-16 is from a well in a small alluvial-filled valley at the west edge of the Galiuro volcanic mountains. The water comes from rain and snow melt in the Galiuro Mountains. The water is not in equilibrium with chalcedony but with quartz from volcanic rocks. The quartz geothermometer approximates the mean annual temperature at the well site. 
RECORO IOCA IOM MUMBER

78014212209 620132121444 $600132105 C 00$

+61DL32LOEAAC $770142117 C A O$ 7) 0142012C3D $07014200113 \mathrm{~A}$ $58013202472 A$ 42 D122011040 6) 01320000 $5701320270 C \mathrm{C}$ $760142034 \mathrm{CAA}$ $75014203439 \mathrm{C}$ 240142033440 $41012200034 A$ $7201420390 \mathrm{Cn}$ 20 D142009900 $710142000 C A$ 68 DI420003an 59 DIJZOJPCAD 360132007.001 $52013191200 \mathrm{C}$

N $\quad 540131924 C C C$

36 DIIITIOOCA 5i O131 IIODCA $060141027 \mathrm{CDC}$ $5301312219 A 4$ 49 OLIOAOCOA 29 DIOLJOIDA $370111931 \mathrm{CCO}$ 9 DOBI HE 3OAD SS $0131330 \mathrm{CCD}$ $47013140141 A$ 40 DI?IM130नC 3901219135.9 4 A D $131911 \mathrm{AAD}$ $330111214 C 00$ 10. DOAIAl 4 ifC 13008132240 3d DIZIJOTMAA $2701019033 A 0$ 11 DOALAISCAA B DOBIPIOC

2 d 0102821340

12 DOAICITAM

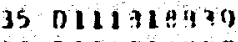

220091224000
$3212.11711011,05051-01-19$ $217.73311012 .30078-10-0$ $3219.553 \quad 11013.63378-10-06$ $320.167 \quad 110 \quad 14.30078-10-06$ $110.14 .500 \times 50-11-30$ $13.65011015 .46765-01-01$ $214.95011015 .46750-11-29$ $217.46711015 .60046-04-05$ 224.100 110 $16.150 \quad 50-11-2$ $3218.00011016 .58351-07-12$ $3216.96711016 .600 \quad 52-05-27$ $3210.28311017 .233 \quad 78-03-10$ $310.61711017 .61754-04-0$ $3210.63111017 .750 \cdot 65-05-0$ $224.633,11018.71750-11-15$ $113.46711019003370-00-06$ 213.467110 19.033 $78-06-06$ 2. 13.900 110 19.267 $70-06-06$ 2. $13.76711019 .53350-10-1$ $214.133 \quad 11019.53350-10-13$ $213.417,11019.91778-10-0$ $218.68311020 .250 \times 33-06-02$ 3218,900 In $21.350 \quad 76-08-0$ $3217.033 \quad 11021.850 \quad 50-10-11$ $3218.967 \quad 11023.28350-10-13$ $3229.250 \quad 11023.36751-06-15$ 1218.867 10.23.383 46-07-0 $3210.783 \quad 11023.43350-11-2$ $17.80911024 .500,78-08-10$ $1219.75011024 .51750-10-1$ $3232.28311026 .46751-06-1$ $3225.70011026 .033 .50-11-02$ $3244.03311026 .90051-02-0$ $3216.167 \quad 11026.31778-08-1$ $32.30 .383120 .27 .10051-01-26$ 2.23 $300 \quad 110-2708370-06-07$ 3) $76-06-0$

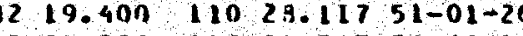
32 $29.25011029 .56719-08-16$ 3244.203 110 2B. $76751-05-02$ $3243.400 \quad 1102 \% .033 \quad 51-02-0$ 32 25.5A3 110 29.15062-09-16 $3235.83311020 .533 .54-07-30$ $1244.16711029 .70073-06-1$ $3244.917 \quad 11027.83351-05-29$ 3232.950 in 70.267 7a-06-21 $3244.237 \quad 110 \quad 31.057 \quad 72-11-20$ 22.750 in $33.0007 \mathrm{H}-08-14$ $3237.1111033 .25073-06-15$

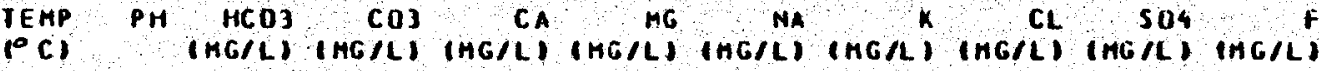

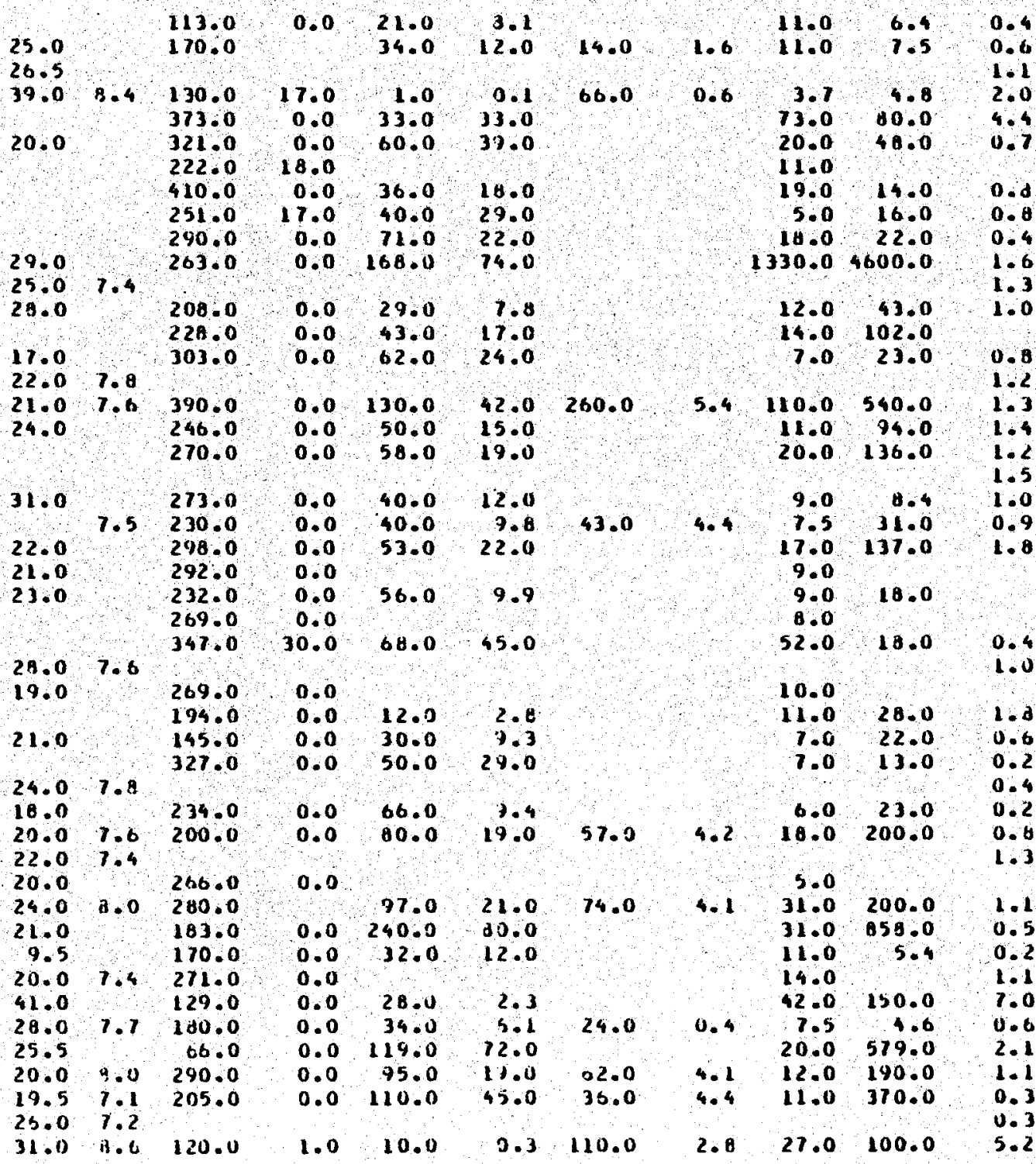

+ Hookers Hot Springs 


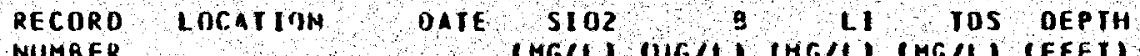

\begin{tabular}{|c|c|c|c|c|c|c|}
\hline 78 & $0142122 C H 3$ & $51-01-19$ & 12.0 & & 130.0 & 705.0 \\
\hline 62 & 0172121494 & $7 \cdot-10-03$ & 34.0 & 30.0 & 208.0 & \\
\hline 60 & $0132105 C 00$ & $79-10-06$ & & & & \\
\hline-61 & D132106AAC & $7 s-10-06$ & $4 t .0$ & 70. & 207.0 & \\
\hline 77 & $0142119 \mathrm{CAD}$ & $\sin -21-30$ & 22.0 & & 562.0 & 644.0 \\
\hline 73 & $0142012 C 9 D$ & $45-01-01$ & 24.0 & & 376.0 & 12.0 \\
\hline 67 & D14200193A & $5 n-11-29$ & & & & \\
\hline 58 & D13202490A & $46-04-05$ & & & 390.0 & $3 \mathrm{~d} .0$ \\
\hline 42 & 0122011040 & $50-1 \mid-21$ & 78.0 & & 329.0 & 312.0 \\
\hline 63 & 01327090 & $51-07-12$ & 53.0 & & 334.0 & \\
\hline 57 & $01320230 \mathrm{CC}$ & $52-05-27$ & 29.0 & & 9160.0 & \\
\hline 76 & DI 2 CIACAA & $1 a-0 a-10$ & & & & 145.0 \\
\hline 75 & $014201494 \mathrm{C}$ & $54-04-01$ & 29.0 & & 286.0 & 246.0 \\
\hline 74 & $01420334 A D$ & $55-05-01$ & & & 466.0 & \\
\hline 41 & D1220093AA & $50-11-15$ & 39.0 & & 355.0 & 25.0 \\
\hline 72 & $01420090 C 0$ & 79-06-06 & & & & \\
\hline 70 & $014 ? 00$ A 100 & $78-06-06$ & 31.0 & 570.0 & 1330.0 & \\
\hline 71 & $014200 A C 3 A$ & $50-10-11$ & 32.0 & & 386.0 & 125.0 \\
\hline 63 & DI $4200 A B S D$ & $50-10-13$ & 32.0 & & 484.0 & 30.0 \\
\hline 59 & $0132032 \mathrm{CaO}$ & $10-10-0 \theta$ & & & & \\
\hline 36 & 0132007000 & $37-06-02$ & 37.0 & & & 440.0 \\
\hline 52 & $013191 ? 0 \mathrm{CC}$ & $7 B-08-09$ & 45.0 & 50.0 & 300.0 & \\
\hline 54 & $0131324 C C C$ & $5 n-10-11$ & 31.0 & & 499.0 & 70.0 \\
\hline 50 & 0131010090 & $5 n-10-13$ & & & & 27.0 \\
\hline 36 & DII10100CA & $51-06-15$ & & & 226.0 & 300.0 \\
\hline 51 & $01319100 \mathrm{Ca}$ & $9 B-07-01$ & & & & 102.0 \\
\hline 66 & $0141027 C 0 C$ & $3 n-11-27$ & 37.0 & & 451.0 & 20.0 \\
\hline 53 & $013172194 A$ & $78-08-10$ & & & & \\
\hline 40 & DIT1OOSCOA & $50-10-11$ & & & & 133.0 \\
\hline 24 & $0101930 \mathrm{SOA}$ & $51-06-15$ & 44.0 & & & 490.0 \\
\hline 37 & $0211931 \mathrm{CCO}$ & $50-11-02$ & 45.0 & & 214.0 & \\
\hline 9 & DOAISIJOAD & $31-02-07$ & 53.0 & & 343.0 & \\
\hline 35 & $01319300 \mathrm{CD}$ & $79-08-11$ & & & & \\
\hline 47 & D131 HOIAAA & $51-01-26$ & 19.0 & & & 180.0 \\
\hline 40 & $012191304 \mathrm{C}$ & $7 A-06-07$ & 27.0 & 90.0 & 530.0 & \\
\hline 32 & $0121: 17 C A 3$ & $76-26-07$ & & & & \\
\hline 49 & J13191LAAD & $51-01-26$ & & & & 223.0 \\
\hline 13 & DIIIAICCOD & $1 A-0 B-16$ & 37.0 & 20.0 & 637.0 & \\
\hline 10 & $D O A 1: \angle 4 C O$ & $31-05-02$ & $3 \geq .0$ & & 1410.0 & \\
\hline 13 & DOBIHZ RAO & $51-02-07$ & 57.0 & & 218.0 & \\
\hline 33 & D121HOSAAA & $3 ?-09-16$ & & & & 122.0 \\
\hline 27 & D1019033A0 & $5,4-03-30$ & 41.0 & & & 277.0 \\
\hline 11 & DOOIS15CSA & $711-06-15$ & 53.0 & 20.0 & 220.0 & \\
\hline 8 & DOALHIDC & $51-05-29$ & 32.0 & & 902.0 & \\
\hline 28 & 0101921094 & $|4-0 b-2|$ & 27.0 & 110.0 & 564.0 & \\
\hline 12 & DOALA17ADU & $12-11-20$ & 33.0 & & $720 . n$ & \\
\hline 32 & O11210410 & $7 a-0 a-14$ & & & & \\
\hline 22. & $00+17240) C$ & $73-0 x-15$ & 35.0 & & $352 . n$ & \\
\hline
\end{tabular}

+ Hookers Hot Springs 
RECORD LUCATI UN NUHBER

$60091736 A C 0$ $700817320 \mathrm{AA}$ 230091725049 31 DIIIT24CAC 21 D091723non $190091714 \mathrm{CDH}$ 17 DOOITICDA

1H $0091714 C 0 C$

$2601017 ? 79 C A$

200091727290

$1600917100 C A$

250101715193

40091720 JuA

$2401017059 \mathrm{CA}$

30001719040

32 DL11730AA

10 DIITIAACA

* 43 DL 31 boicc

140091507969

* 6401415030!1 3

* $6501416094 A 9$

N $\quad 1500916099139$

2 DOAI $62010 \mathrm{~A}$

* $4501716200 C$

1 DOELELAONC

* 44 D131419CAO

LONG, IUOE

DATE

TEMP

(HG/L) IHG/L) IMG/L) (HG/L) IHG/L) (HG/L) IHG/L) IHG/L) IHG/L)

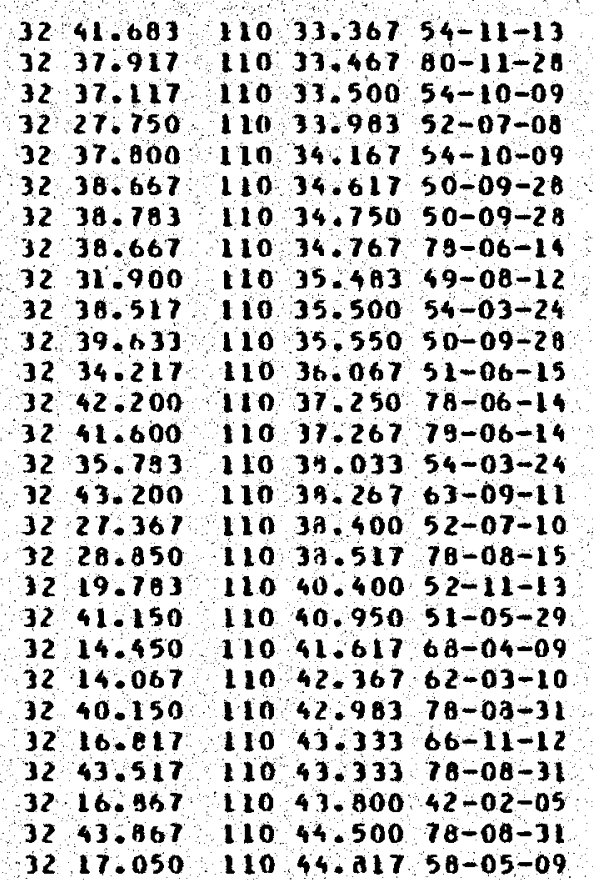

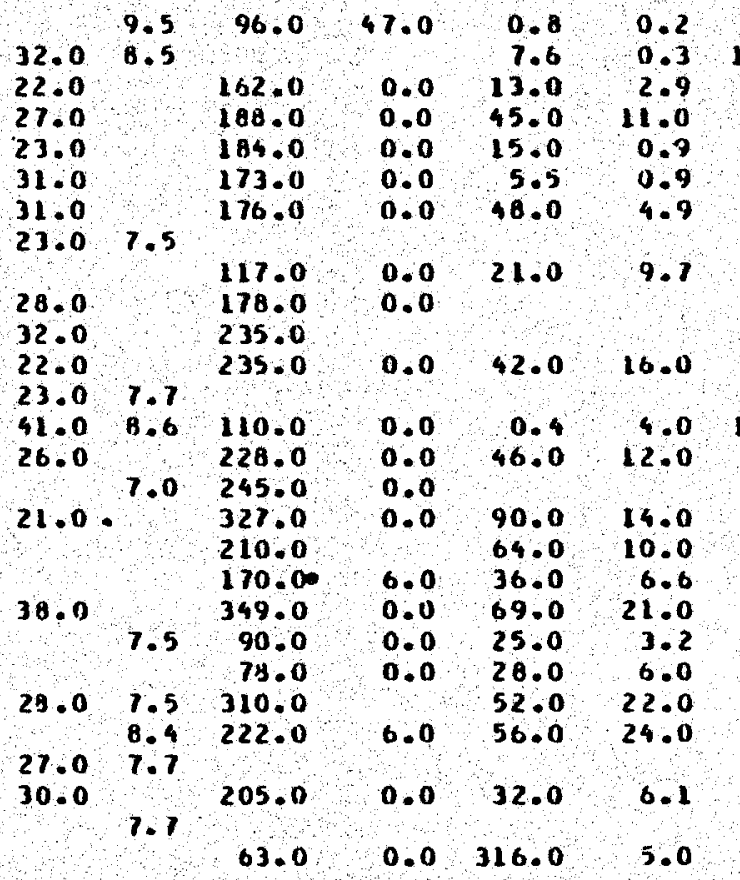

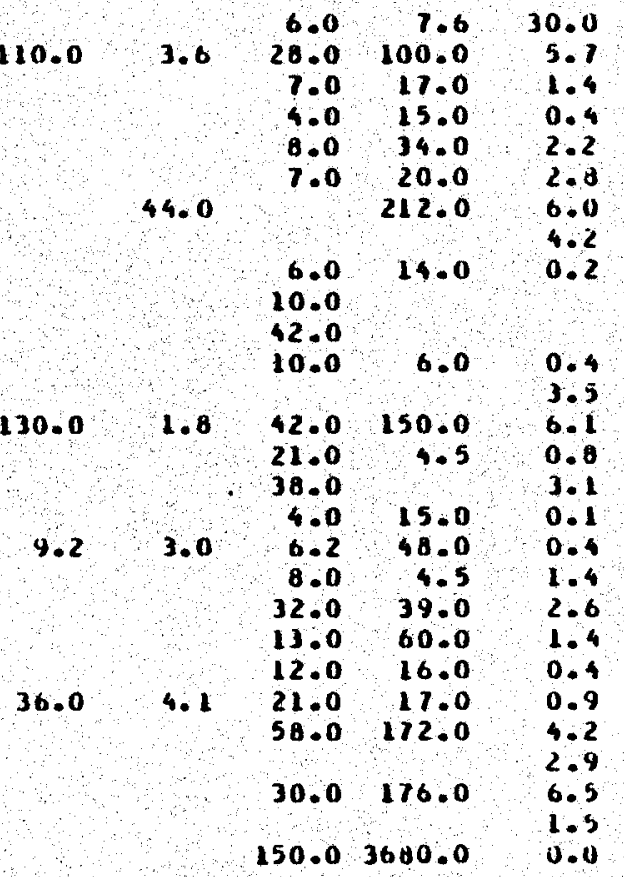

76.

OLL

$24-F+B-B I$

* Tucson wells 
G DOAIT3RACO $54-11-13$

$55.0 \quad 425.0$ $36.0,90.0,200.0351 .0$

37.0

26.0

33.0

$310111724 C A C \$ 2-07-0$ -

$210091723000 \quad 54-10-09$

$190091714 C D O \quad 50-00-29$

$170091714 \cos 50-09-28$

35.0

1005.0

Is Do917i4COC $7 y-06-14$

36,0

54.0

25 DIDI727)CA 49-OA-12

$20009172249954-03-24$

16 D09ITIODCA $50-09-26$

$25010111599951-06-15$

$400 B 172900 A$ 78-06-14

5 BOBI732DAA 74-D6-14

$2401013059 C A$ \$4-03-24

3 DOSINDOAD B3-09-11

32 O111730aAa 52-07-10

30 DIIITAACA 7A-0B-15

43 D13Lsolcc $57-11-13$

140091602340 51-05-29

*64 0141603031 $64-04-09$

*O5 O14IGOQAAA R2-03-10

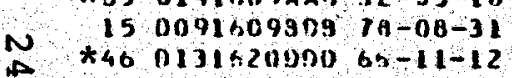

2 OOBIBZOADA $78-00-31$

45013162000 4?-02-05

1 DOEISI OODC 3-00-31

*4401316LOCAD 59-05-09

462.0

10.0
2.0

29.0

285.0

34.0 190.0

434.0

$2 \mathrm{~A} .0$

100.0

11.0

$19.030 .0 \quad 260.0$

$31.0 \quad 237.0$ 1300.0

29.0

213.0

141.0

348.0

$558.0 \quad 200.0$

25.0
25.0

100.0

493.0

$5693.0 \quad 110.0$

Total number al records:

ALL

ALLFEH-AI

* Tucson wel1s

76. 
SAN PEQPN - Table 5

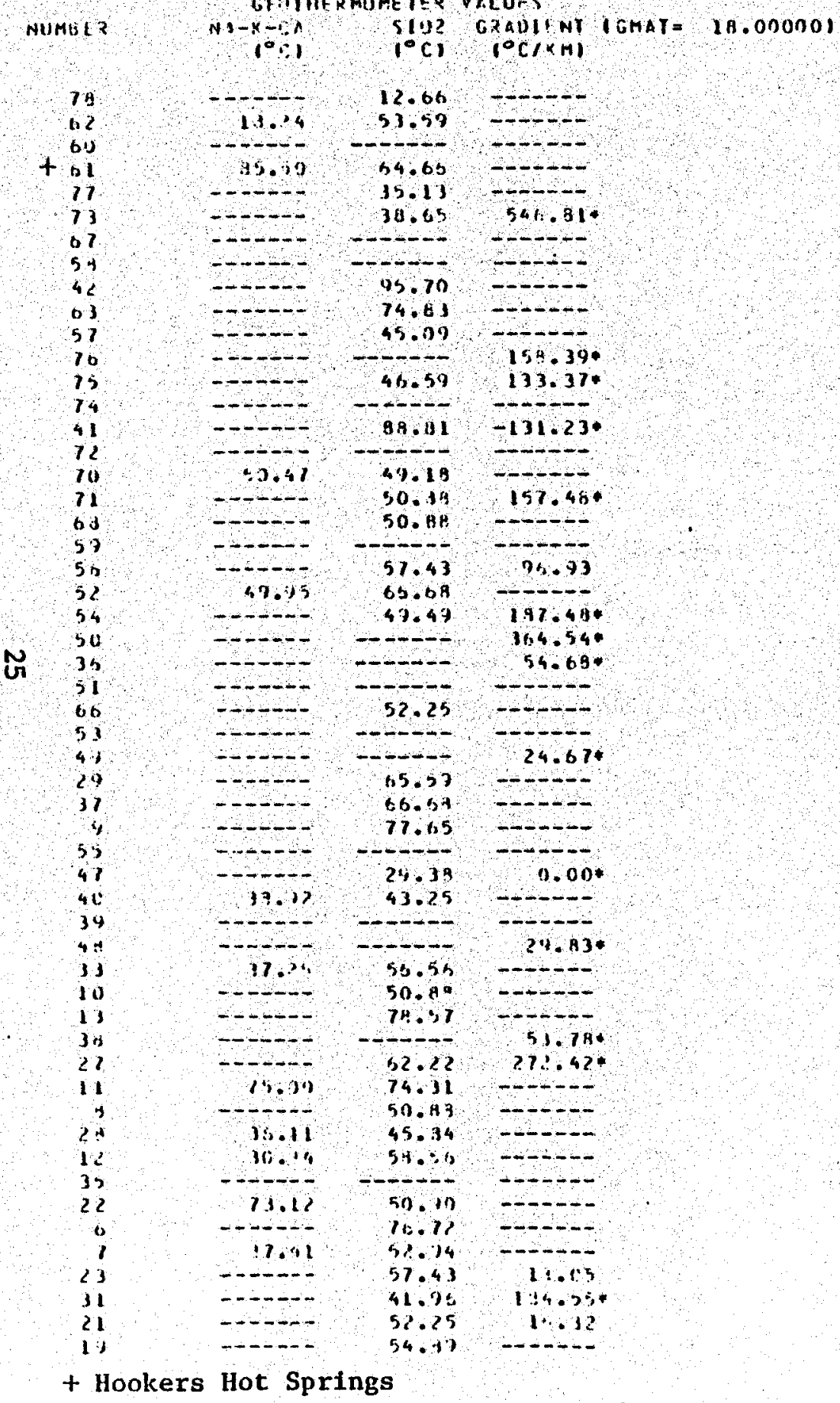


SAIV P(I) 80 - Table 5

COOTHERMOHETEQ YALUS,

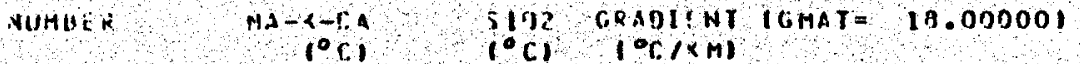

\begin{tabular}{|c|c|c|}
\hline & 34.91 & $733.13 *$ \\
\hline & 50.17 & $-0-0$ \\
\hline- & ----- & 27.64 \\
\hline & $-c$ & $540.37 \%$ \\
\hline & 45.07 & $42.05 *$ \\
\hline$-1+x+3$ & $-\cdots-$ & -- \\
\hline 17.49 & 43.45 & 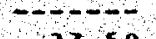 \\
\hline-8 & 45.09 & 37.50 \\
\hline & ----0 & ------6 \\
\hline & 7.70 & $-0--2$ \\
\hline 19.13 & $\int_{-}^{2} e_{-\infty}^{3 n}$ & ----6 \\
\hline$\therefore--$ & 47.49 & 50.47 \\
\hline & 45.119 & --- \\
\hline 41.77 & 40.07 & $----\_-$ \\
\hline & 40.33 & ------ \\
\hline & 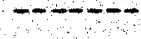 & $--0-6$ \\
\hline & & \\
\hline & & $\ldots \ldots$ \\
\hline
\end{tabular}

N $\star$ Tucson we11s 


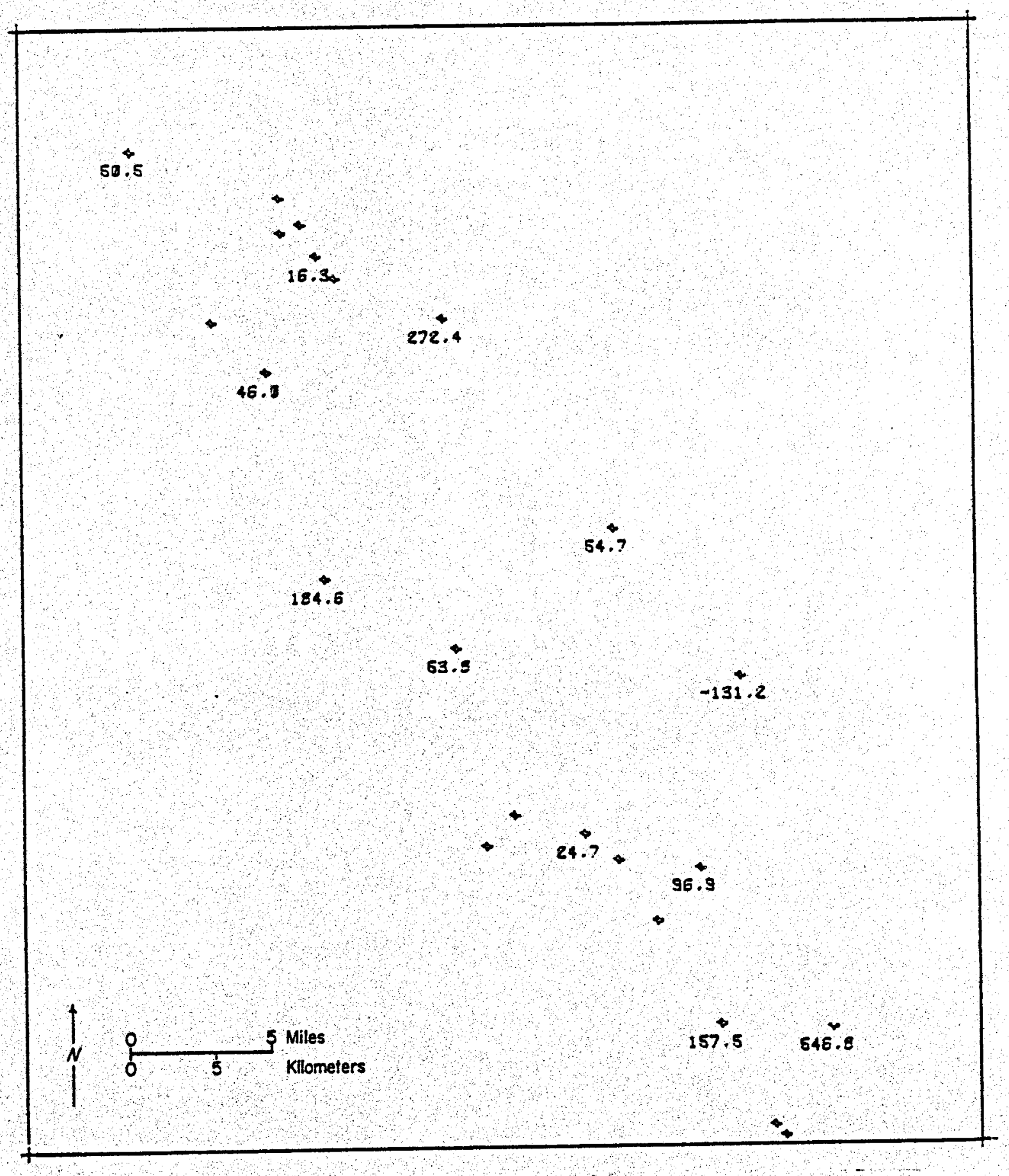

Figure 6. San Pedro geothermal gradients; gradients have been calculated in $\mathrm{c} / \mathrm{km}$. 


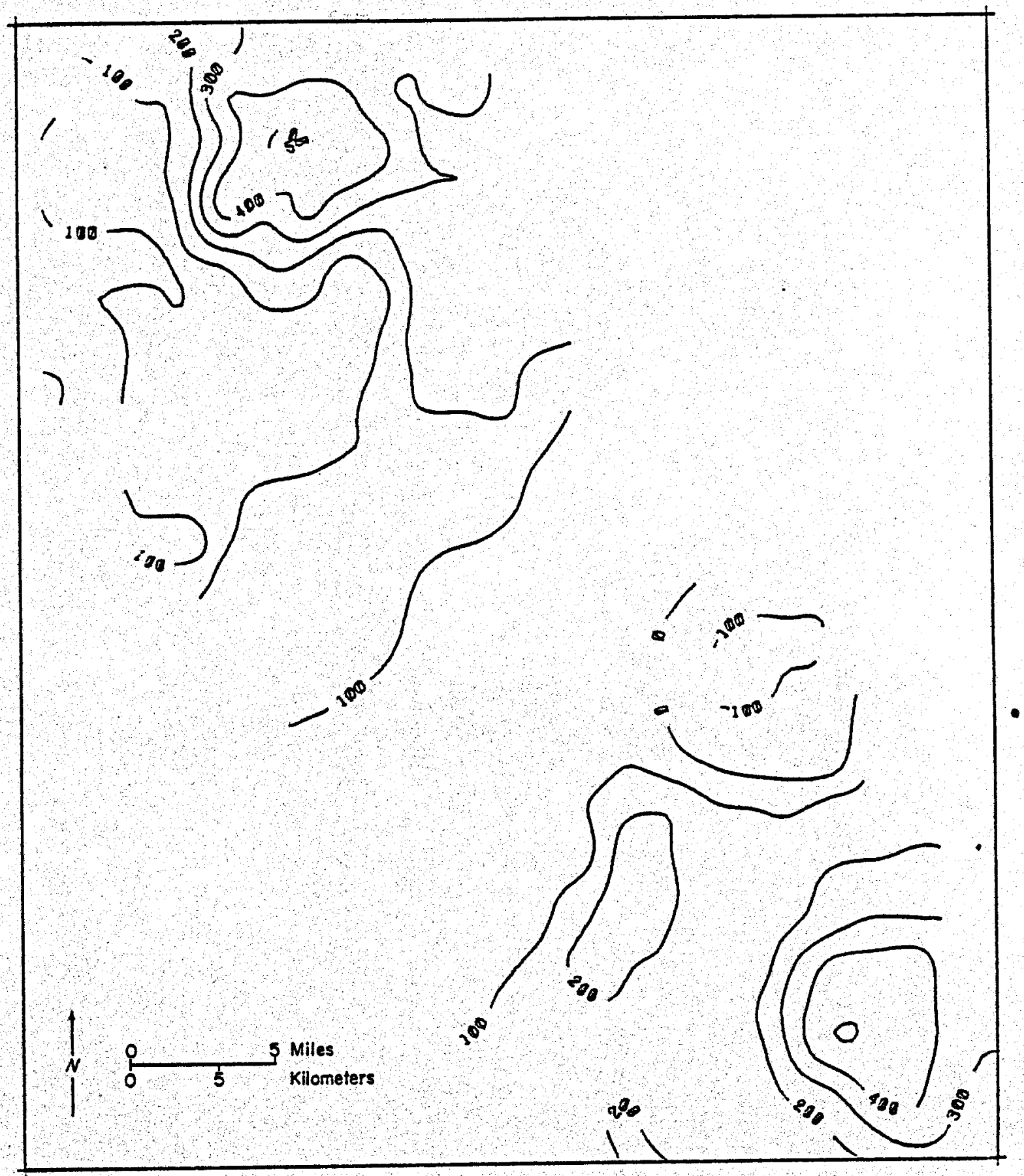

Figure 7. San Pedro: Computer contour map of geothermal gradients; gradients have been calculated in $\mathrm{C} / \mathrm{km}$. 
In Fig. 6 , to avoid crowding, the computer was programmed not to print the value at any point that is within $3 / 4$ of an inch of a previously printed point. Hence some of the high gradients from Table 5 do not appear in Fig. 6 but are reflected in the contours of Fig. 7. Conversely, when the discharge temperature is less than the mean annual temperature, the computer will compute a negative gradient and contour it.

In Fig. 7 the $789+^{\circ} \mathrm{C} / \mathrm{km}$ is reflected in the 400 and $500^{\circ} \mathrm{C} / \mathrm{km}$ contour lines near the town of San Manuel. This very high anomaly is caused by a well with a surface discharge temperature of $31^{\circ} \mathrm{C}$ and a depth of $16.5 \mathrm{~m}(54 \mathrm{ft})$. These gradient anomalies must not be taken literally as these high gradients do not hold at depth. Instead, they merely reflect the presence of warm water at a shallow depth. A more accurate calculated gradient for this area might be obtained from SP-10, which has a measured temperature of $40^{\circ} \mathrm{C}$ and a depth of $452.6 \mathrm{~m}(1485 \mathrm{ft}) . \mathrm{SP}-10$ has a calculated gradient of $48.6^{\circ} \mathrm{c} / \mathrm{km}$ and is in the same cluster of wells along the San Pedro River just east of San Manuel. Table 6 is a compilation of the well gradients in the study area. Wells over $200 \mathrm{~m}$ in depth give a more accurate estimation of the gradient in that area. The very shallow wells, with a lightly higher discharge temperature than the mean annual air temperature, give erroneously high gradients. In all probability, the thermal gradient in the 
TABLE 6

CALCULATED GRADIENTS

OF

SAMPLED WELLS

\begin{tabular}{|c|c|c|c|}
\hline Sample No. & Discharge Temperature & Depth & Gradient \\
\hline$S P-1$ & $18^{\circ} \mathrm{C}$ & $30.48 \mathrm{~m}$ & 0 \\
\hline $\mathrm{SP}-2$ & $20^{\circ} \mathrm{C}$ & $30.48 \mathrm{~m}$ & $65.61^{\circ} \mathrm{C} / \mathrm{km}$ \\
\hline $\mathrm{SP}-3$ & $20^{\circ} \mathrm{C}$ & $33.53 \mathrm{~m}$ & $59.65^{\circ} \mathrm{C} / \mathrm{km}$ \\
\hline $\mathrm{SP}-4$ & $20^{\circ} \mathrm{C}$ & $30.48 \mathrm{~m}$ & $65.61^{\circ} \mathrm{C} / \mathrm{km}$ \\
\hline$S P-5$ & $20^{\circ} \mathrm{C}$ & $18.29 \mathrm{~m}$ & $109.36^{\circ} \mathrm{C} / \mathrm{km}$ \\
\hline $\mathrm{SP}-10$ & $40^{\circ} \mathrm{C}$ & $452.60 \mathrm{~m}$ & $48.60^{\circ} \mathrm{C} / \mathrm{km}$ \\
\hline$S P-11 *$ & $31^{\circ} \mathrm{C}$ & $30.48 \mathrm{~m}$ & $426.51^{\circ} \mathrm{C} / \mathrm{km}$ \\
\hline$S P-12$ & $31^{\circ} \mathrm{C}$ & $265.18 \mathrm{~m}$ & $49.02^{\circ} \mathrm{C} / \mathrm{km}$ \\
\hline$S P-13$ & $30^{\circ} \mathrm{C}$ & $251.46 \mathrm{~m}$ & $47.72^{\circ} \mathrm{C} / \mathrm{km}$ \\
\hline$S P-14$ & $30^{\circ} \mathrm{C}$ & $259.08 \mathrm{~m}$ & $46.32^{\circ} \mathrm{C} / \mathrm{km}$ \\
\hline$S P-15+$ & $23.5^{\circ} \mathrm{C}$ & $294.74 \mathrm{~m}$ & $18.66^{\circ} \mathrm{C} / \mathrm{km}$ \\
\hline$S P-16$ & $21^{\circ} \mathrm{C}$ & depth not available & \\
\hline
\end{tabular}

Calculated with a mean annual alr temperature of $18^{\circ} \mathrm{C}$

$*$

${ }^{*}$ SP-11 is within 100 feet of SP-12 which is now abandoned and its casing is in deplorable condition. It would be reasonable to assume lateral migration of warm water through rusted out casing into the production zone of SP-11.

+ SP-15 1s Well \#2 at Magma Copper Company. The we11 is reported "hot" arteslan well by the U.S. Geologlcal Survey on the Peppersauce Wash $7 \frac{1}{2}$ minute topographlc quadrangle, Section $25, \mathrm{~T}, 9 \mathrm{~s}, \mathrm{R}, 17 \mathrm{E}$. on tables 4 and 5 record number 23 is another Magma Copper Company well in the same section with a measured temperature of $22^{\circ} \mathrm{C}$, a depth of $306.6 \mathrm{~m}$, and a gradient of $13.05^{\circ} \mathrm{c} / \mathrm{km}$. These very $10 \mathrm{w}$ gradlents do not approximate the average gradient for the Basin and Range province of $30^{\circ} \mathrm{C} / \mathrm{km}$. These wells are part of the well field that supplies water to the Magma mill and smelter. The only explanation for these anomalously low gradients is that the wells for one reason or another are no longer producing from the horizon in which they bottomed or from which they orfginally produced. 
San Manuel area of the San Pedro River valley is 47 or $48^{\circ} \mathrm{C} /$ $\mathrm{km}$.

similarly in the southeast corner of Fig. 6 , the gradient $546.8^{\circ} \mathrm{C} / \mathrm{km}$, well record 73 , is generated by a well with a measured temperature of $20^{\circ} \mathrm{C}$, two degrees above mean annual air temperature, and a depth of $3.67 \mathrm{~m}(12 \mathrm{ft}$ ). This extremely high gradient again points out the problem of using gradients from shallow wells. Calculated gradients, assuming no infusion of cold water up hole, assume a degree of reliability when the depth of the well is $300 \mathrm{~m}$ ( $1000 \mathrm{ft})$ or greater. Measured gradients in water wells over $100 \mathrm{~m}$ (328 ft) deep have proved to be the most accurate means of establishing a geothermal gradient.

Figure 8 is a computer plot of the $\mathrm{SiO}_{2}$ geothermometers. The geothermometers were calculated for equilibrium with chalcedony. The $\mathrm{SiO}_{2}$ geothermometers reflect a lowto moderate-temperature geothermal resource possibly at a depth of $1 \mathrm{~km}$ or less.

Figure 9 is a computer generated contour map of the $\mathrm{SiO}_{2}$ data shown in Fig. 8. The $90^{\circ} \mathrm{C}$ contour reflects Hookers Hot Springs. The contour map appears to indicate an overall increase in geothermometer temperatures from west to east. However, there is no available data in the Galiuro Mountains. Again, it should be pointed out that the $\mathrm{SiO}_{2}$ and $\mathrm{Na}-\mathrm{K}-\mathrm{Ca}$ geothermometers were developed to predict high temperature, $>150^{\circ} \mathrm{C}$, geothermal resources, not 


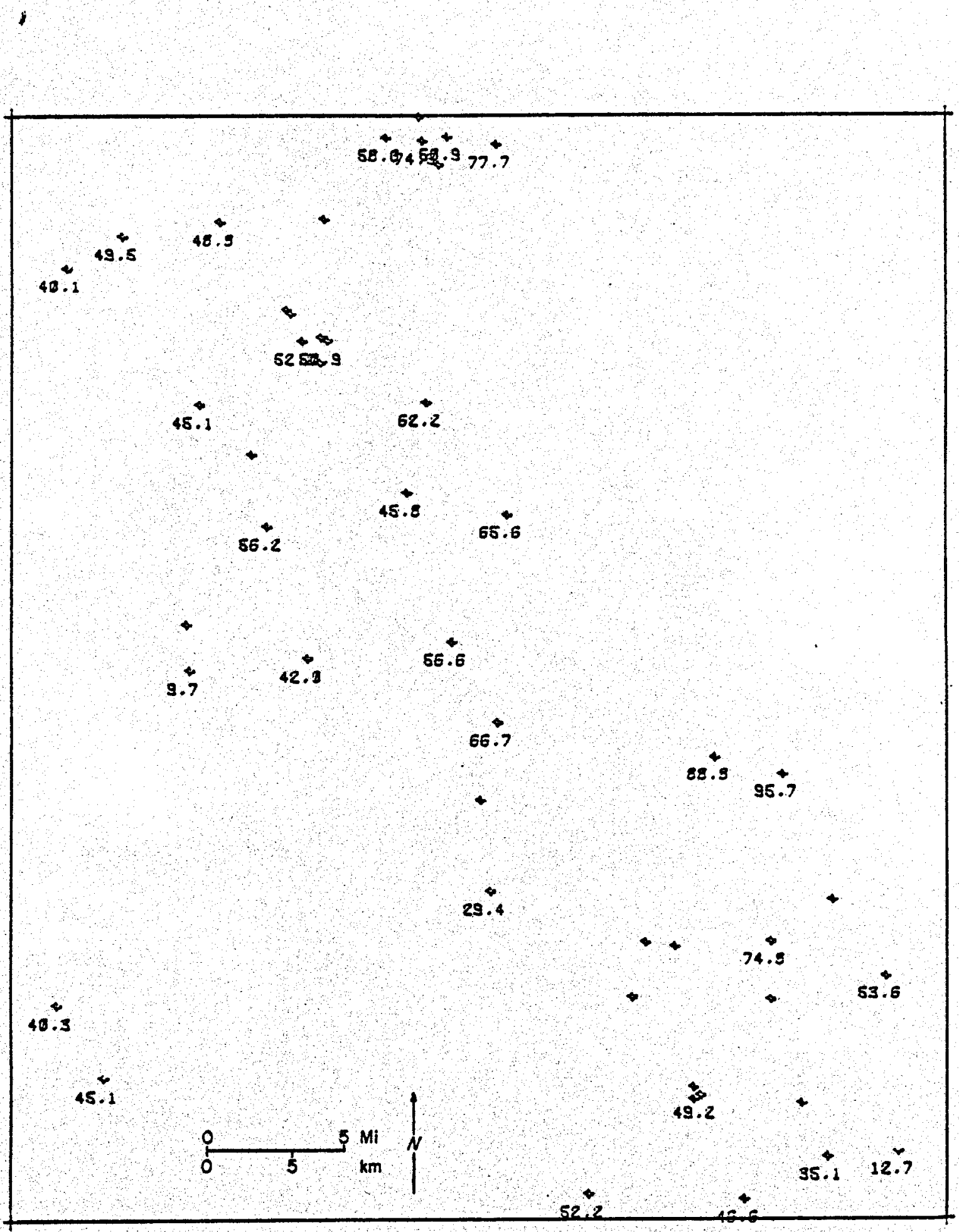

Figure 8. San Pedro: $\mathrm{SiO}_{2}$ geothermometer temperatures in ${ }^{0} \mathrm{C}$. 
U

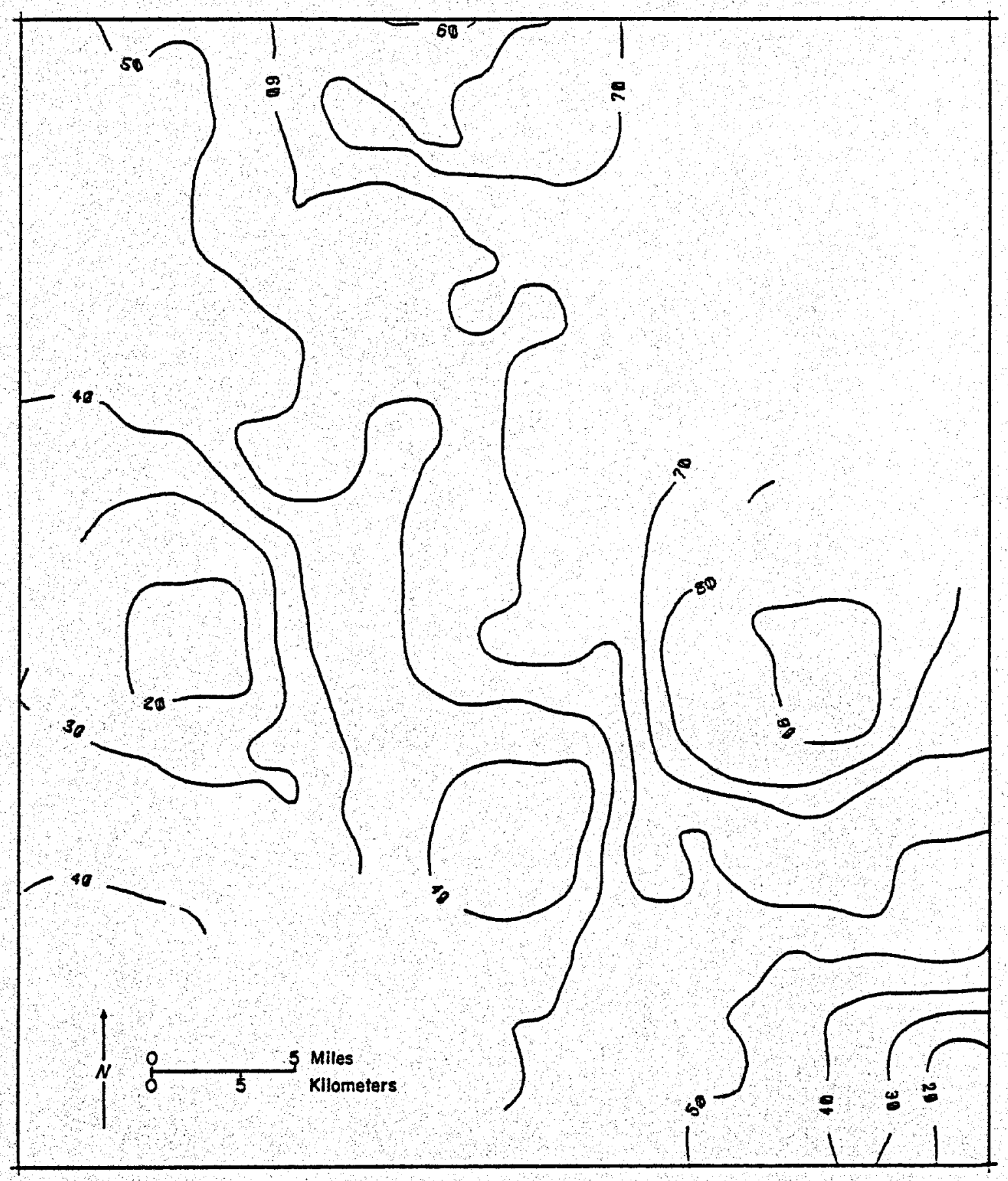
Figure 9. San pedro: Computer contour map of $\mathrm{SiO}_{2}$ geothermometer tem- 
low- to moderate-temperature resources. Therefore, with the possible exception of Hookers Hot Springs, the geothermometers may indicate only that the water in the basin alluvial fill has had more time to dissolve silica or has been in contact with a more soluble form of silica.

Figure 10 is a plot of the available Na-K-Ca geothermometers from the WATSTORE files. Because of the paucity of points the data were not contoured. Again great caution should be taken in the interpretation of this geothermometer.

Figure 11 shows the $\mathrm{SiO}_{2}$ geothermometer versus measured temperature. The warmer wells appear to have a maximum "reservoir(?)" temperature between 45 and $65^{\circ} \mathrm{C}$ assuming reliability of the geothermometer. The highest geothermometer, $\approx 90^{\circ} \mathrm{C}$, and the lowest geothermometer, $\approx 10^{\circ} \mathrm{C}$, come from wells with discharge temperatures approximating the mean annual temperature for the region. These results may indicate the presence of silica that is not totally dependent upon temperature for its solubility.

Hookers Hot Springs, a former spa, is located in cochise County, Arizona, at the Muleshoe Ranch, section 6 , T. $13 \mathrm{~s}, \mathrm{R}, 21 \mathrm{E}$. Table 7 is the chemical data from Hookers Hot springs and springs in the immediate vicinity. The geothermometer temperatures for the different springs vary from $118-134^{\circ} \mathrm{C}$ for $\mathrm{Na}-\mathrm{K}-\mathrm{Ca}$ and from $95-105^{\circ} \mathrm{C}$ for $\mathrm{siO}_{2}$ (quartz conductive). Therefore, the minimum reservoir temperature for this hot spring system might be expected to be 


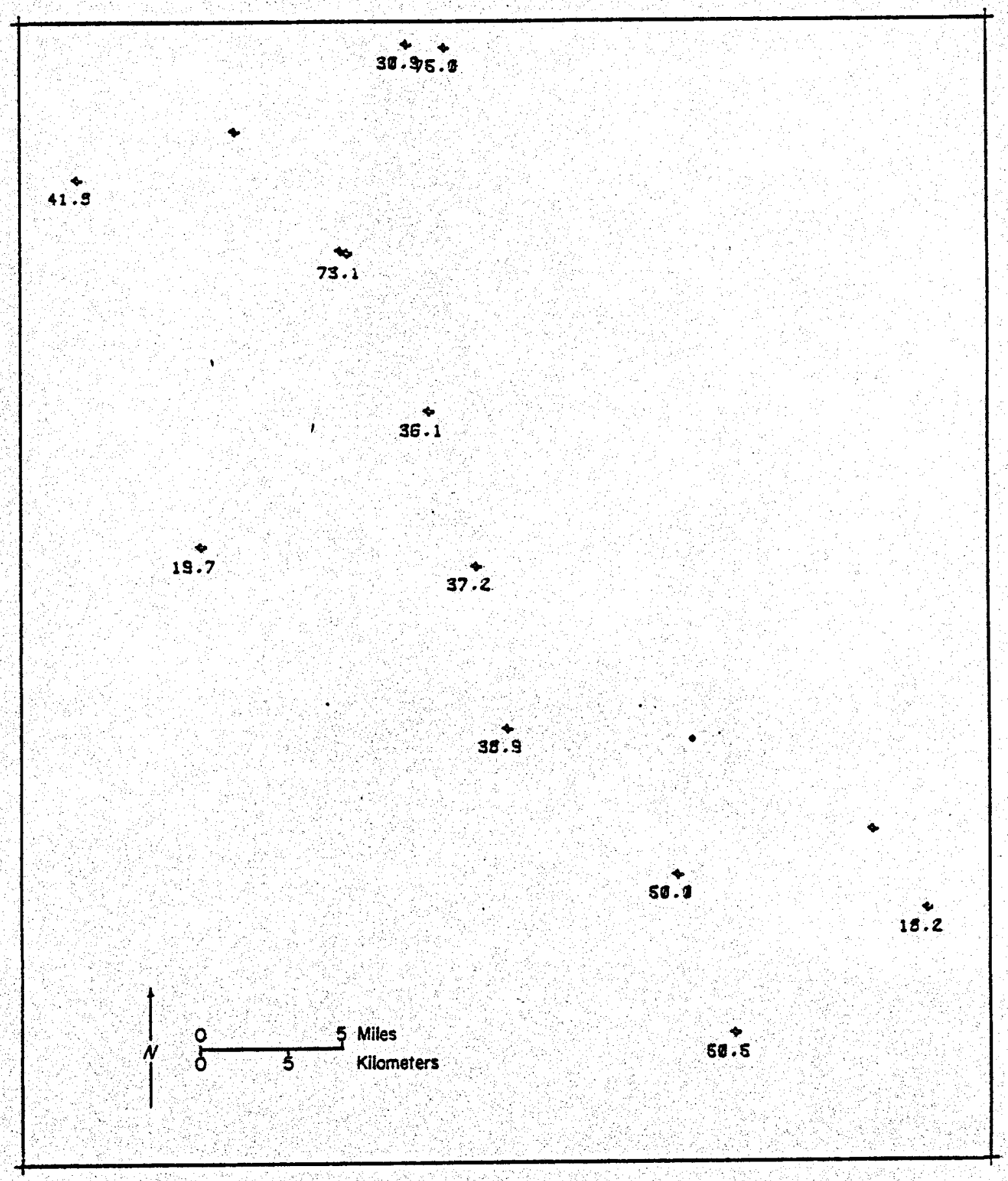

Figure 10. San Pedro: Na-K-Ca geothermometer temperatures in ${ }^{\circ} \mathrm{C}$. 


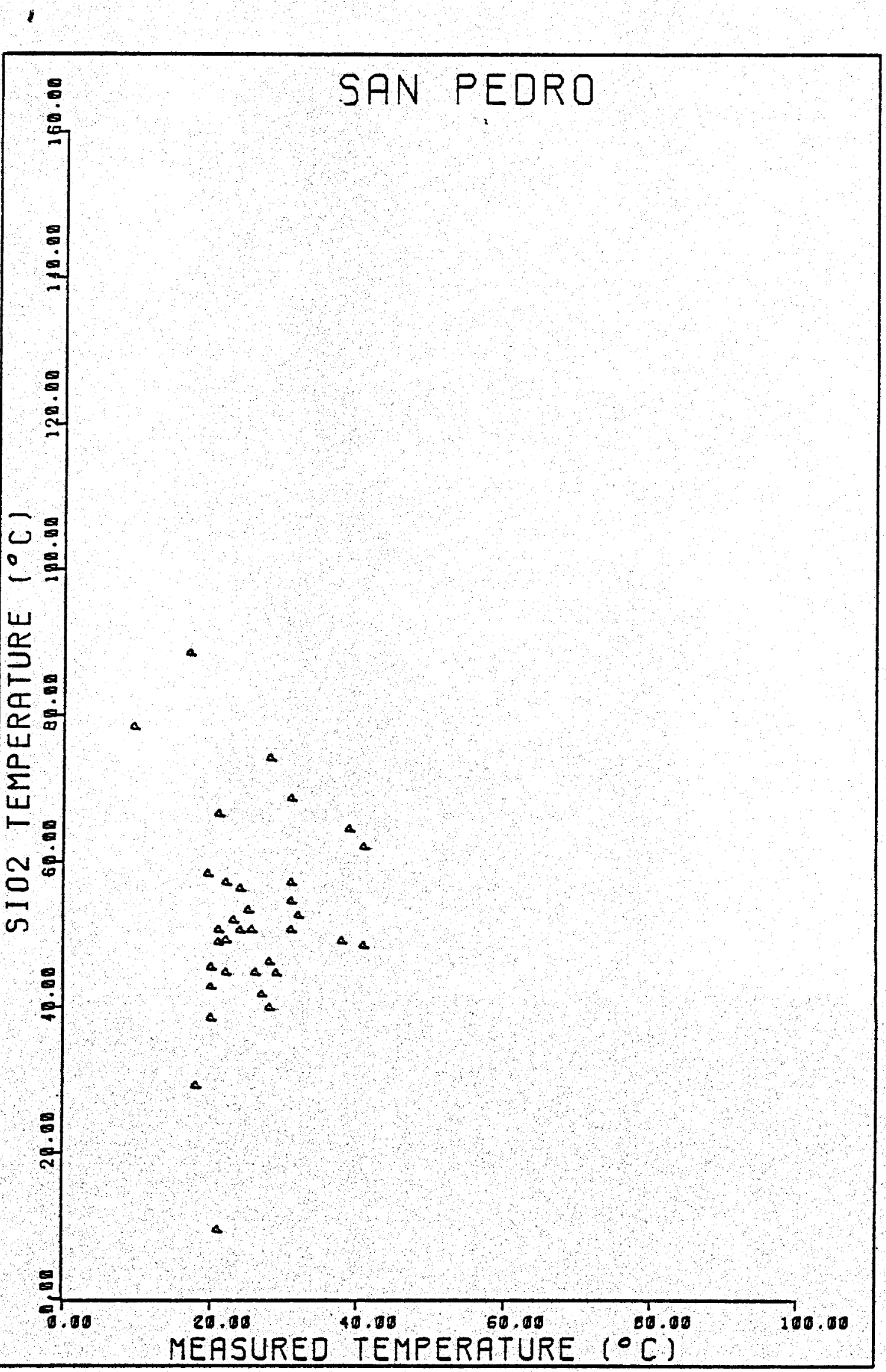

Figure 11. San Pedro: Computer plot of $\mathrm{SiO}_{2}$ geothermometer versus the measured well discharge temperature. 
TABLE 7

CHEMICAL ANALYSES

HOOKERS HOT SPRINGS*

\begin{tabular}{|c|c|c|c|c|c|c|c|c|c|c|}
\hline Sample \# & Name & $\begin{array}{l}\text { Township } \\
\text { location }\end{array}$ & $\begin{array}{l}\text { Sample } \\
\text { date }\end{array}$ & Temp. & $\begin{array}{l}\text { Flow } \\
\text { (est.) }\end{array}$ & $\begin{array}{l}\text { Fleld } \\
\mathrm{pH}\end{array}$ & $\mathrm{Na}$ & K & $\mathrm{Ca}$ & $\mathrm{Mg}$ \\
\hline $3 W 80$ & $\begin{array}{l}\text { Hookers } \\
\text { hot } \\
\text { springs }\end{array}$ & $\begin{array}{l}\text { T13S, R21E, Sec, } 6 \\
\text { NE } \frac{1}{4}, N^{\frac{1}{4}}, S W \frac{1}{4}, S W \frac{1}{4}\end{array}$ & $4 / 15 / 80$ & $52.0^{\circ} \mathrm{C}$ & $10 \mathrm{gpm}$ & 9.21 & 28.6 & 0.79 & 0.23 & 0.05 \\
\hline $4 W 80$ & $\begin{array}{l}\text { Hookers } \\
\text { hot } \\
\text { springs }\end{array}$ & $\begin{array}{l}\text { T13S, R21E, Sec, } 6 \\
\mathrm{NE}^{\frac{1}{4}}, \mathrm{NW}^{\frac{1}{4}}, \mathrm{SE}^{\frac{1}{4}}, \mathrm{NE}^{\frac{1}{4}}\end{array}$ & $4 / 15 / 80$ & $51.0^{\circ} \mathrm{C}$ & $5 \mathrm{gpm}$ & 9.22 & 31.6 & 0.76 & 0.25 & 0.06 \\
\hline $5 W 80$ & $\begin{array}{l}\text { Hookers } \\
\text { hot } \\
\text { springs }\end{array}$ & $\begin{array}{l}\mathrm{T} 13 \mathrm{~S}, \mathrm{R} 21 \mathrm{E}, \mathrm{Sec}, 6 \\
\mathrm{NE}^{\frac{1}{4}}, \mathrm{NW}^{\frac{1}{4}}, \mathrm{SE}^{\frac{1}{4}}, \mathrm{SW}^{\frac{1}{4}}\end{array}$ & $4 / 15 / 80$ & $40.0^{\circ} \mathrm{C}$ & $5 \mathrm{gpm}$ & 9.22 & 31.0 & 0.74 & 0.20 & 0.02 \\
\hline 6 W80 & $\begin{array}{l}\text { "cold" } \\
\text { sprtng }\end{array}$ & $\begin{array}{l}\text { T12S, R21E, Sec, } 31 \\
\mathrm{NE}^{1} \frac{1}{4}, \mathrm{NW}^{1} \frac{1}{4}, \mathrm{SE}^{\frac{1}{4}}, \mathrm{SW}^{\frac{1}{4}}\end{array}$ & $4 / 16 / 80$ & $18.0^{\circ} \mathrm{C}$ & $1 \mathrm{gpm}$ & 7.15 & 66.0 & 1.39 & 1.83 & 4.80 \\
\hline 7W80 & $\begin{array}{l}\text { "warm" } \\
\text { spring }\end{array}$ & $\begin{array}{l}\mathrm{T} 12 \mathrm{~S}, \mathrm{R} 21 \mathrm{E}, \mathrm{Sec} \cdot 31 \\
\mathrm{NE}^{\frac{1}{4}}, \mathrm{SW}_{4}^{\frac{1}{4}}, \mathrm{SE}^{\frac{1}{4}}\end{array}$ & $4 / 16 / 80$ & $29.0^{\circ} \mathrm{C}$ & $<2 \mathrm{gpm}$ & 9.05 & 26.9 & 0.54 & 0.35 & 0.12 \\
\hline $8 W 80$ & $\begin{array}{l}\text { "warm" } \\
\text { spring }\end{array}$ & $\begin{array}{l}\text { T12S, R21E, Sec. } 31 \\
\mathrm{NE}^{\frac{1}{4}}, \mathrm{SW}^{\frac{1}{4}}, \mathrm{SE}^{\frac{1}{4}}\end{array}$ & $4 / 16 / 80$ & $32.5^{\circ} \mathrm{C}$ & $\sim 2 \mathrm{gpm}$ & 9.15 & 28.1 & 0.52 & 0.31 & 0.05 \\
\hline
\end{tabular}

* A11 data from J.C. Witcher, Arizona Hot Springs study 
Table 7

Chemlcal Analyses, con't.

Hookers Hot Springs

\begin{tabular}{|c|c|c|c|c|c|c|c|c|c|c|}
\hline $\mathrm{CO}_{3}$ & $\mathrm{HCO}_{3}$ & C1 & $\mathrm{SO}_{4}$ & $\mathrm{SiO}_{2}$ & F & LI & B & TDS & Geology & Samp1e \\
\hline 34 & 80 & 9 & 2 & 51 & 1.85 & 0.14 & 0.45 & 180 & $\begin{array}{l}\text { Volcanoclastic sediment } \\
\text { Tertlary age }\end{array}$ & 3 W80 \\
\hline 42 & 88 & 6 & 3 & 51 & 2.61 & 0.11 & 0.86 & 169 & $\begin{array}{l}\text { Volcanoclastic sediment } \\
\text { Tertiary age }\end{array}$ & $4 W 80$ \\
\hline 30 & 78 & 6 & 3 & 54 & 2.55 & 0.12 & 0.35 & 178 & $\begin{array}{l}\text { Volcanoclastic sediment } \\
\text { Tertiary age }\end{array}$ & $5 W 80$ \\
\hline 0 & 299 & 12 & 21 & 79 & 2.61 & 0.22 & 0.85 & 428 & $\begin{array}{l}\text { Volcanoclastic sediment } \\
\text { Tertiary age }\end{array}$ & $6 W 80$ \\
\hline 40 & 66 & 8 & 1 & 47 & 2.15 & 0.10 & 0.85 & 157 & $\begin{array}{l}\text { Volcanoclastic sediment } \\
\text { Tertiary age }\end{array}$ & $7 w 80$ \\
\hline 24 & 76 & 7 & 2 & 47 & 1.52 & 0.10 & 0.50 & 159 & $\begin{array}{l}\text { Volcanoclastic sediment } \\
\text { Tertiary age }\end{array}$ & $8 \mathrm{~W} 80$ \\
\hline
\end{tabular}


$100^{\circ} \mathrm{C}$, indicative of a low- to moderate-temperature resource. Both the writer and witcher (pers, commun., 1980) infer that Hookers Hot Springs is structurally controlled. The exact structural details have not as yet been resolved. Figure 12 is a plot of the measured temperatures recorded in the WATSTORE file. Hookers Hot Springs has been indicated on the map. The $39^{\circ} \mathrm{C}$ temperature recorded in Table 4 is from one of the lesser springs. The temperatures of the main springs at Hookers Hot Springs are in excess of $50^{\circ} \mathrm{C}$.

The only other thermal well found during this study is on the property of A. C. Gruwell. This well is situated in the $\mathrm{NW}_{\frac{1}{4}}, \mathrm{SE}_{\frac{1}{4}}, \mathrm{NW}_{4}^{\frac{1}{4}}$, Section $3, \mathrm{TIOS}, \mathrm{R} 18 \mathrm{E}$ and is erroneously reported in the WATSTORE file, record 27 , as SE $\frac{1}{4}, N E \frac{1}{4}, N W^{\frac{1}{4}}$, Section 3, TIOS, R18E. At the scale of the maps and plots in this report this quarter mile discrepancy makes no difference. This well has a measured temperature of $41^{\circ} \mathrm{C}$, a depth of $84.4 \mathrm{~m}(277 \mathrm{ft})$ and a calculated gradient of $272.5^{\circ} \mathrm{C} / \mathrm{km}$, which is excessive. The well is situated in Cienega Wash and is collared in the Quiburus Formation. A possible explanation for this well, which is west of the Galiuro Mountains and reported to be artesian, rising to within $50 \mathrm{ft}$ of the surface (Gruwell, pers. commun., 1981), is warm water rising along a fault, possibly one of the basin bounding faults, and then moving laterally to- 


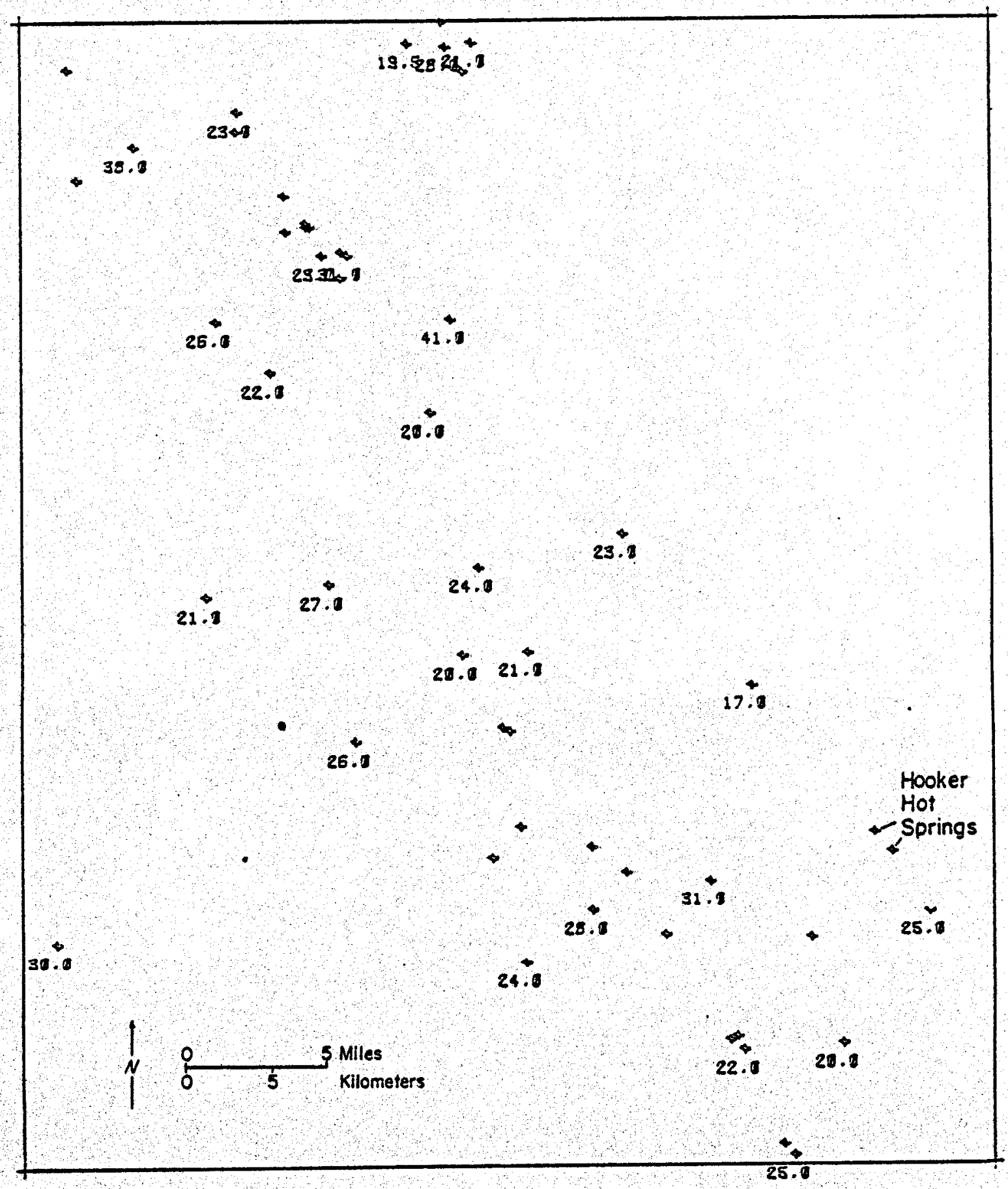

Figure 12. San Pedro measured temperatures in ${ }^{\circ} \mathrm{C}$. 
wards the center of the valley through an aquifer in the Quiburus Formation.

Figure 13 is a computer contour map of the measured temperature data. Again, the higher points are averaged with the lower points but the anomalous areas are still reflected in the map. It is interesting to note that in the northwest corner of the map the warm temperature of the water $\left(38^{\circ} \mathrm{C}\right.$ at $\left.396 \mathrm{~m}\right)$ from a mine shaft at san Manuel indicates another anomalous area.

Figures 14 and 15 are a plot and contour map respectively of the total dissolved solids (TDS) in the study area. With the exception of one well in the Tucson (southwest corner of maps) area and three wells in the southeast corner of the map, all the reported TDS analyses are less than 1000 milligrams per liter (mg/1). The water quality in the San Pedro valley with respect to TDS is very good, generally less than $500 \mathrm{mg} / 1$. The high TDS in the southeast corner of the map is not the result of Hookers Hot Springs, which has a TDS of less than $500 \mathrm{mg} / 1$. Instead, it apparently reflects local sediment conditions in the Teran basin where the midale lithologic unit composed of sandstone, shale and mudstone contains gypsiferous mudstone (Scarborough and Wilt, 1979).

In an attempt to define the water of the $S$ an Pedro valley two triangular diagrams and five $x-y$ plots were 


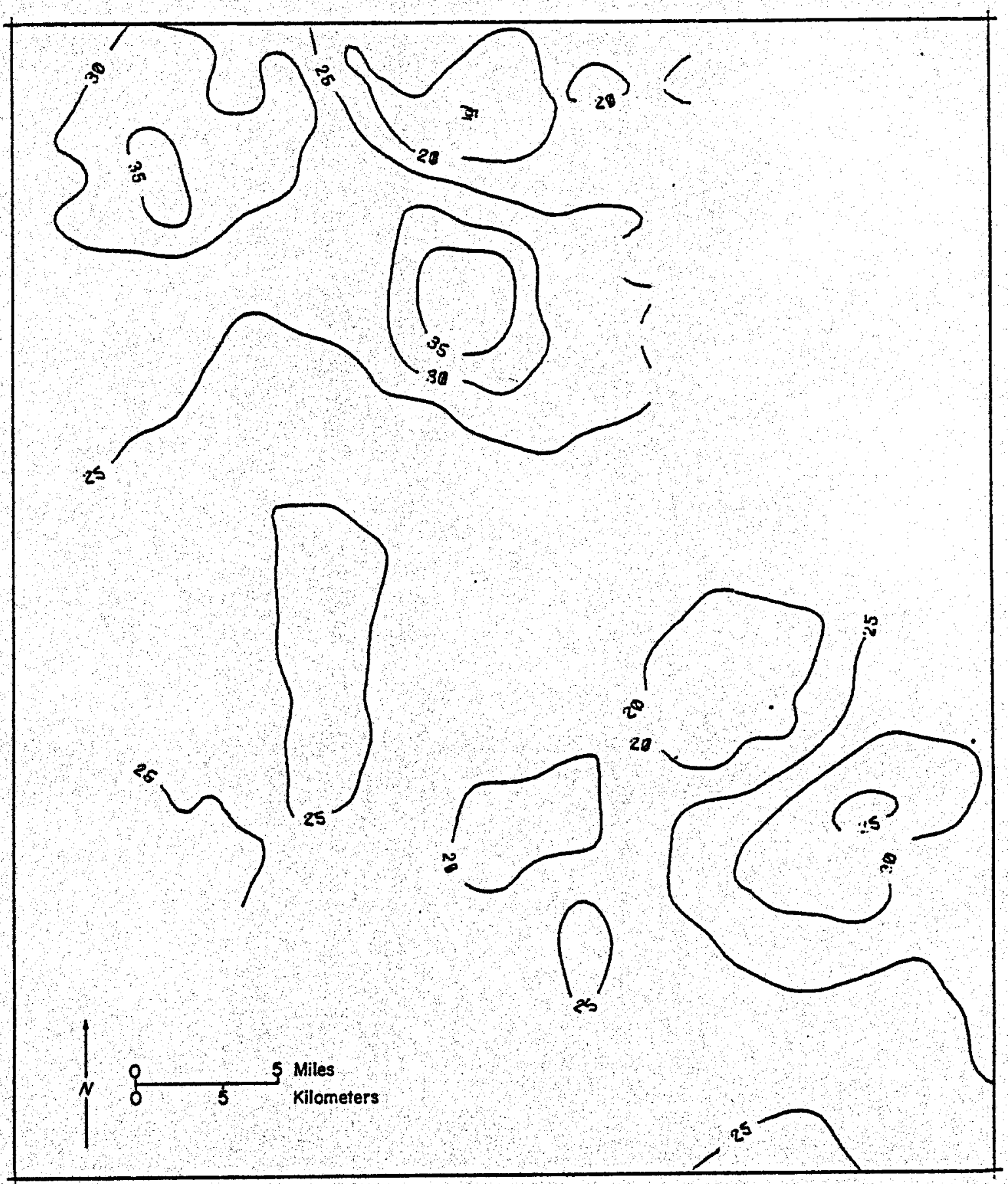

Figure 13. San pedro: Computer contour map of measured temperatures in ${ }^{\circ}$. 


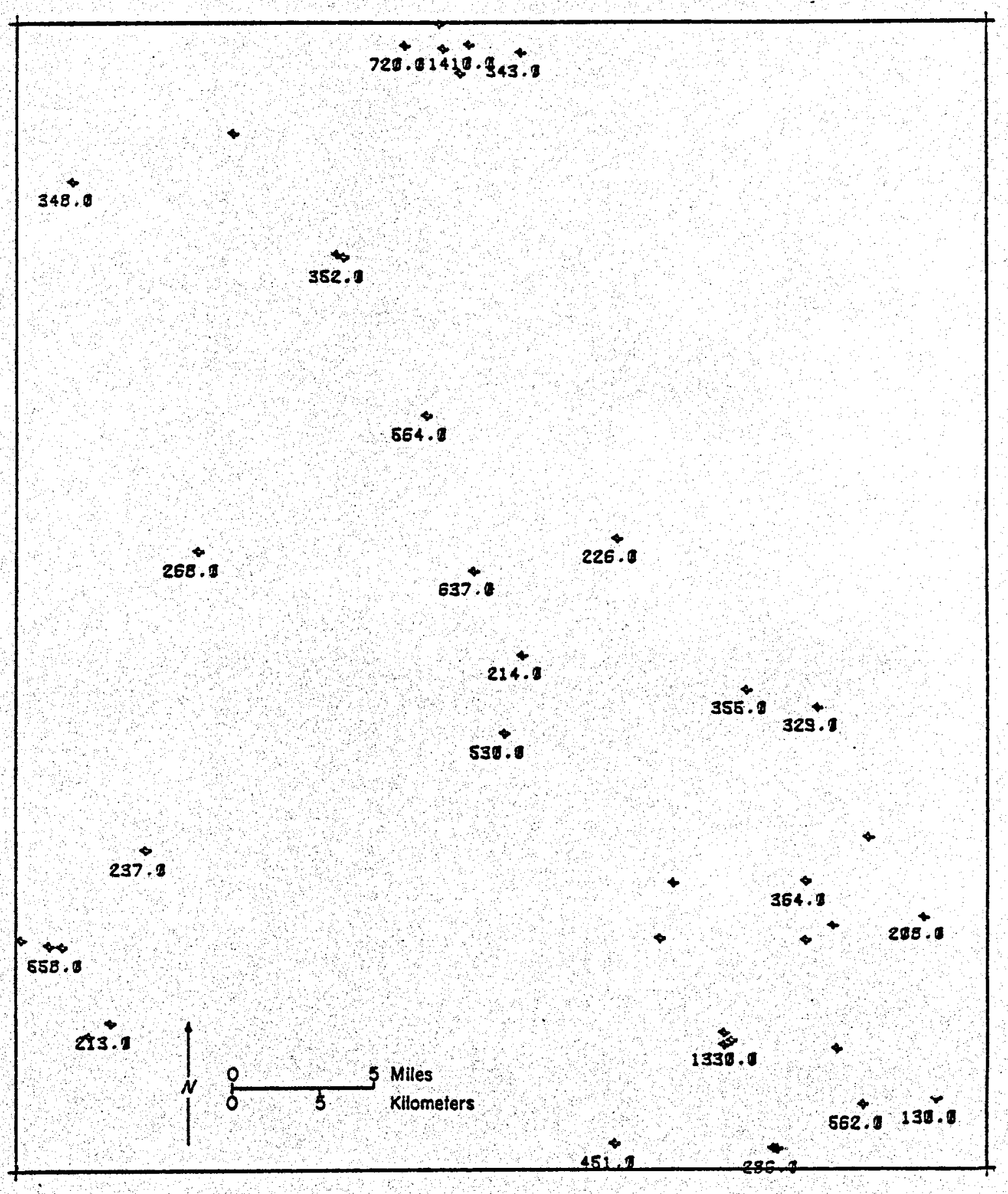

Figure 14. San Pedro: Total dissolved solids (TDS) in milligrams per liter (mg/l). 


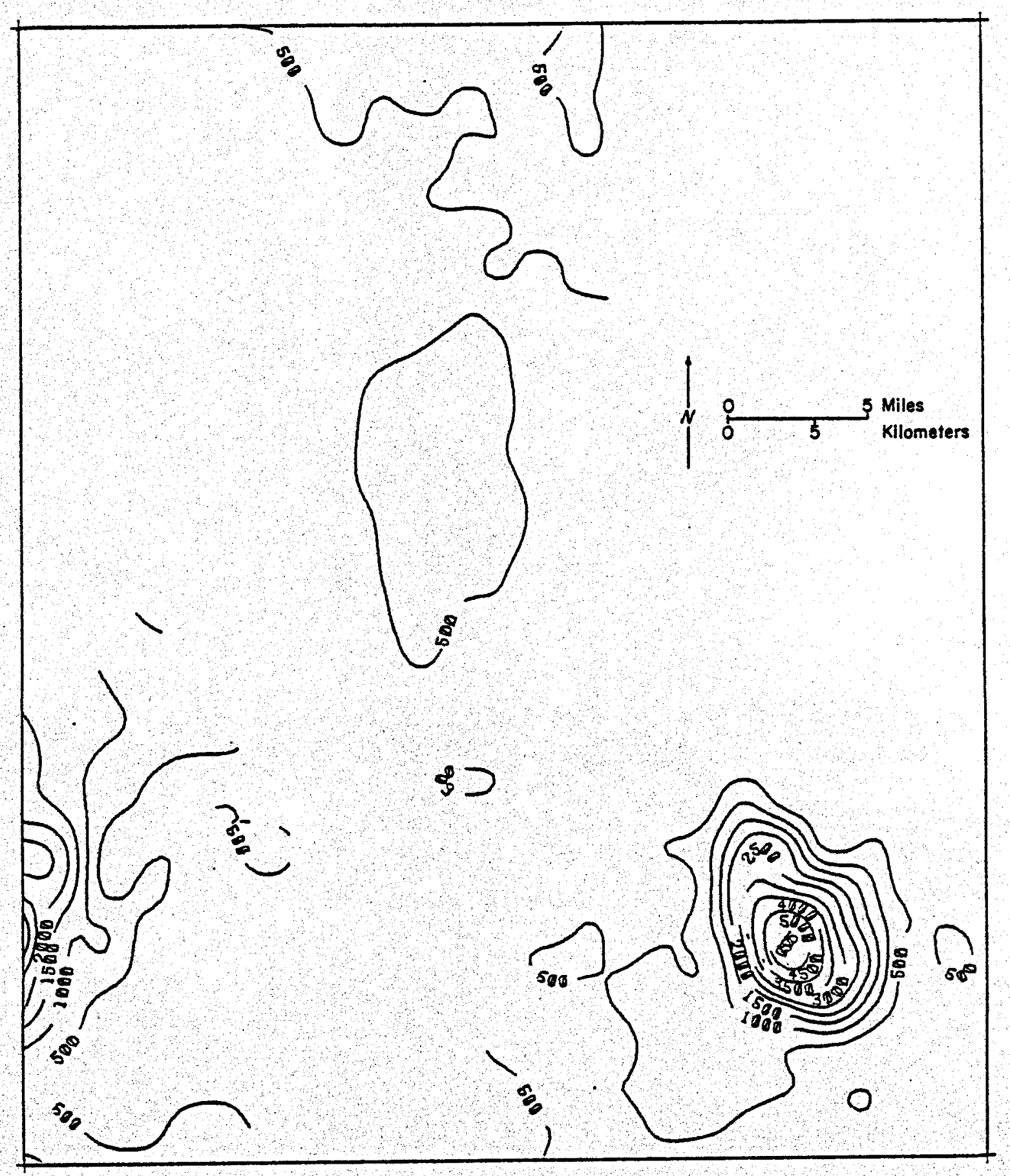

Figure 15. San Pedro: Computer contour map of total dissolved solids (TDS) in milligrams per liter (mg/ 1 ). 
generated. Geothermal waters will often have excessive concentrations of boron, fluorine, chlorine and sulfate. Comparisons of these elements and compounds will often designate different waters and mix waters in the same geographical area as well as indicate geothermal water.

The first triangular diagram (Fig. 16) is a plot of Ca-Mg-Na. Where complete analyses are available the water is primarily a calcium-sodium ( $\mathrm{Ca}-\mathrm{Na}$ ) water low in magnesium (Mg). Those analyses where sodium (Na) is the dominate cation appear to be from the Teran basin.

The second triangular diagram (Fig. 17) is a plot of $\mathrm{HCO}_{3}-\mathrm{SO}_{4}-\mathrm{Cl}$. Where complete analyses are available the water is primarily a bicarbonate $\left(\mathrm{HCO}_{3}\right)$ water. Those analyses where sulfate $\left(\mathrm{SO}_{4}\right)$ is the dominate anion are from the Teran basin where there is gypsum in the muds tone beds.

From the two triangular diagrams the water in the San pedro valley study area may be classified as a calciumsodium bicarbonate water. This type of water appears, from prior work in Arizona, to be one of the more common types of ground water in the Basin and Range province of the state.

Figure 18 shows a comparison of the $\mathrm{SiO}_{2}$ versus the Na-K-Ca geothermometer temperatures. There appears to be reasonable correlation between the geothermometers, given the inadequacies of the geothermometers applied to low- 


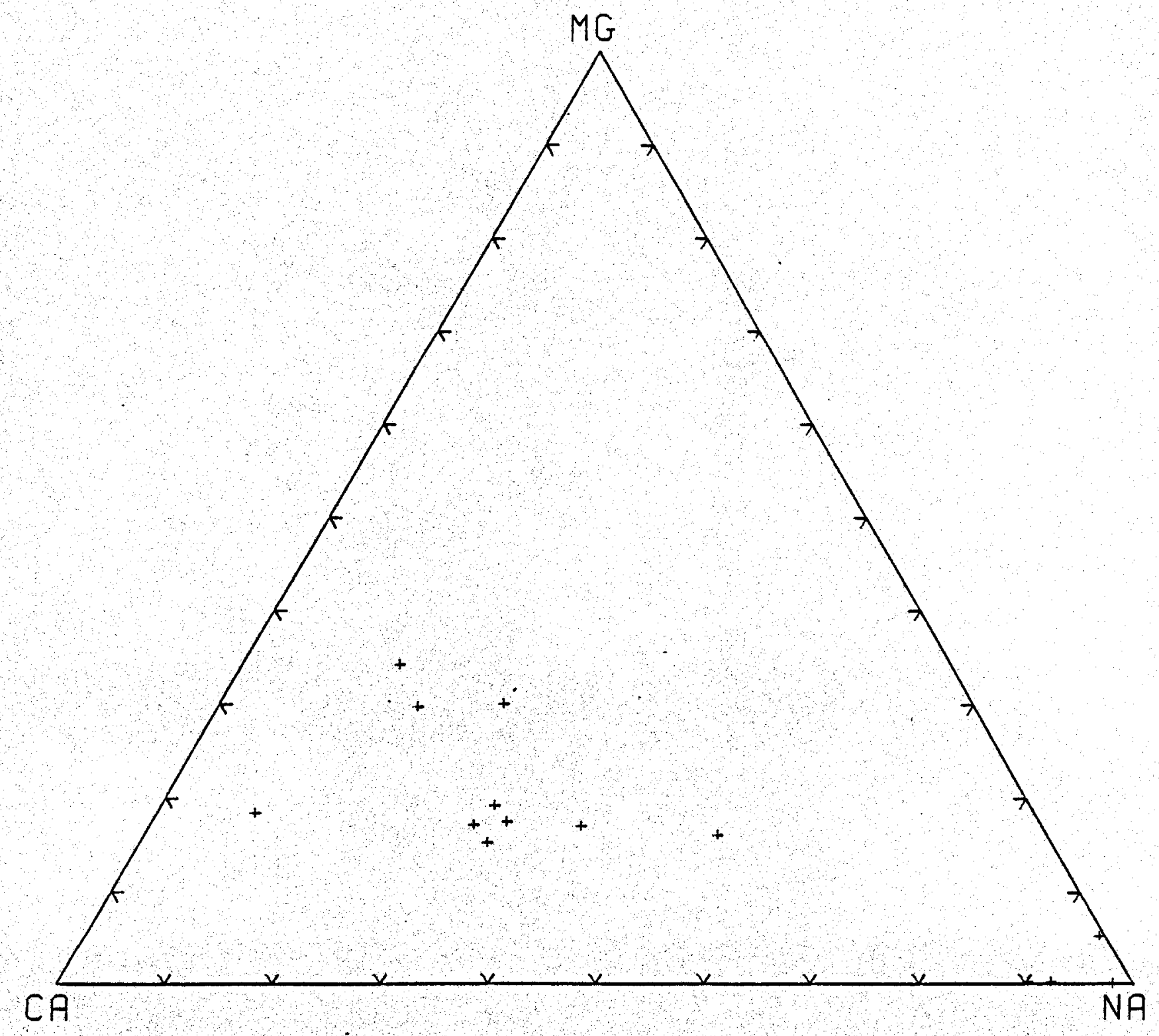

Figure 16. San Pedro triangular diagram of the cations Na-Ca-Mg from available WATSTORE analyses. 


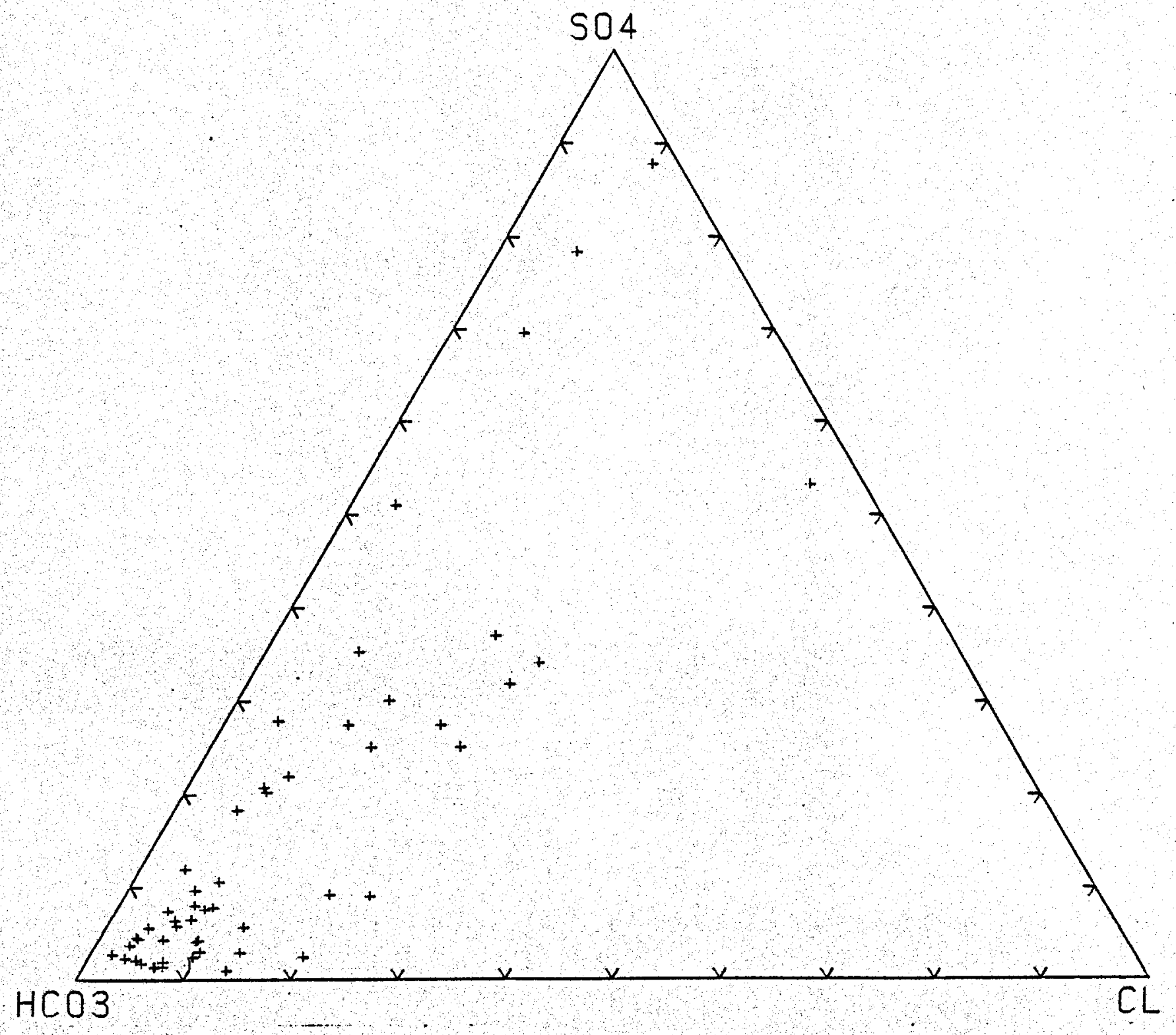

Figure 17. San Pedro triangular diagram of the anions $\mathrm{Cl}-\mathrm{HCO}_{3}-\mathrm{SO}_{4}$ from available HATSTORE analyses. 


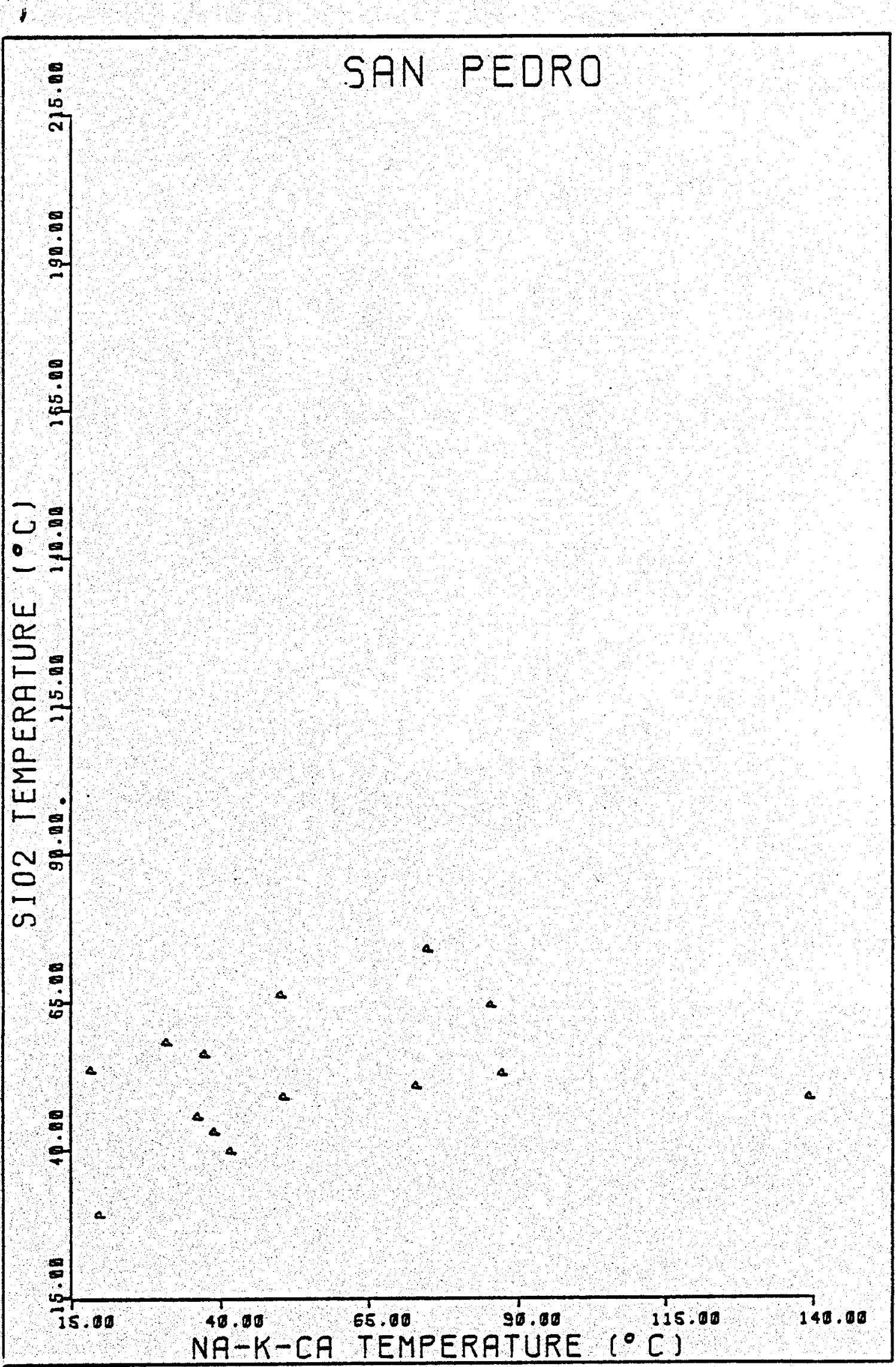

Figure 18. San Pedro: Computer plot of $\mathrm{Na}-\mathrm{K}-\mathrm{Ca}$ geothermometer versus $\mathrm{SiO}_{2}$ geothermometer. 
temperature resources. The point at the far right of the diagram indicating reservoir temperatures of 139.40 (Na-KCa) and $48.85\left(\mathrm{SiO}_{2}\right)$ is well record 5 , which is also sP-10. This warm artesian well was drilled in 1937 as an oil test. The well bottomed at approximately $453 \mathrm{~m}(1485 \mathrm{ft})$ in what is apparently Quiburus Formation. The original flow was estimated to be 20 gallons per minute from a $29 \mathrm{~m}$ (95 ft) thick sandstone at a depth of 1275-1370 ft (Roeske and Werrel1, 1973). The writer, during this study, measured a temperature of $40^{\circ} \mathrm{C}$ and estimated the flow at 5 gallons per minute. In all probability the casing has deteriorated, permitting the influx up hole of sediments and cooler water. Again, great care should be taken in using the geothermometers on Iow- to moderate-temperature resources. Too many unknown chemical reactions can take place as the ground water migrates through the diverse lithologies of the basins.

Figures 19 and 20 , computer plots of chlorine versus measured temperature and boron versus measured temperature, indicate that the presence of these two elements are not temperature dependent but are apparently dependent upon lithology.

Figure 21 is a computer plot of chlorine versus fluorine. There is no apparent relationship between the concentration of chlorine and fluorine in the water. 


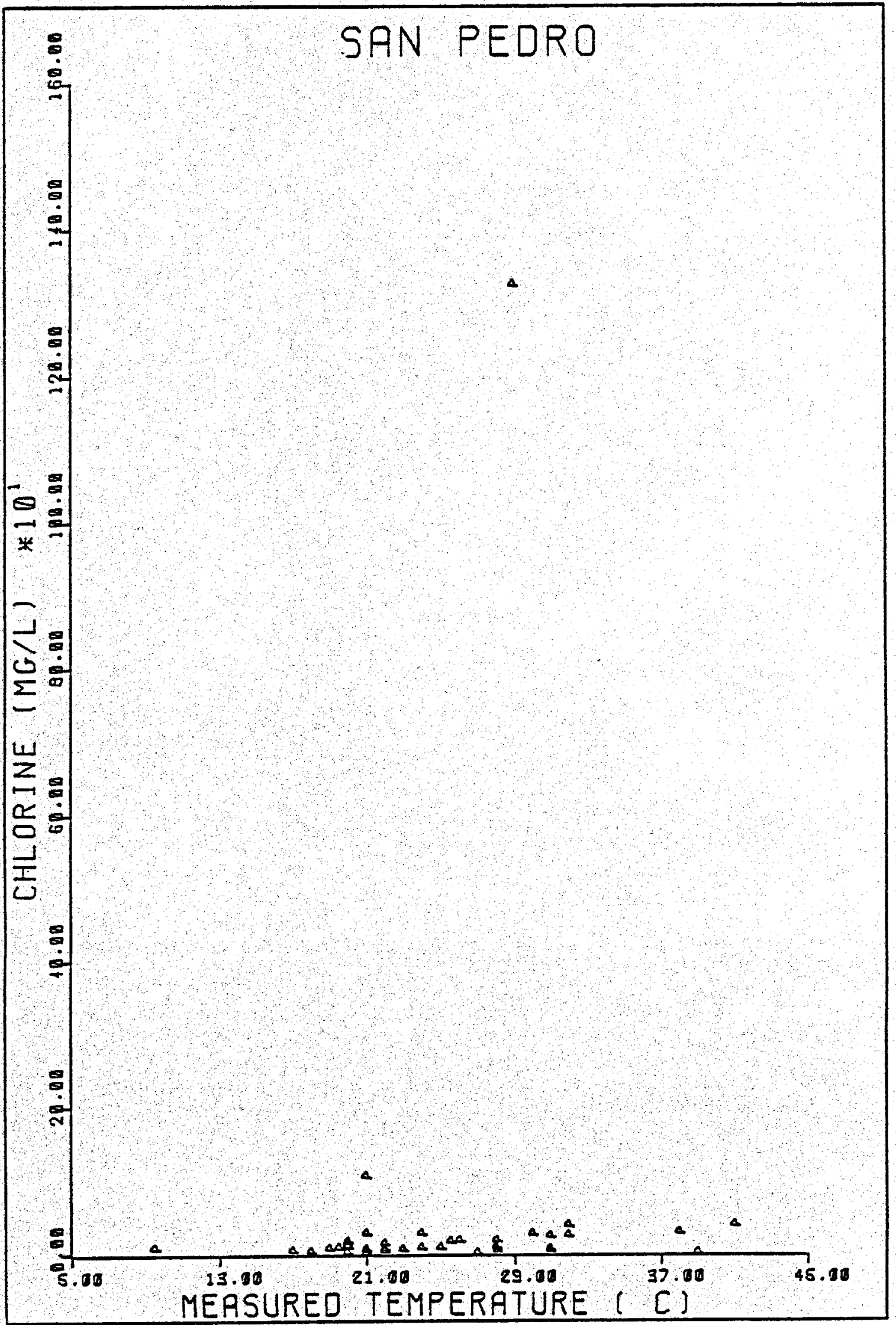

Figure 19. San Pedro: Computer plot of chlorine concentration (mg/1) versus the measured well discharge temperature. 


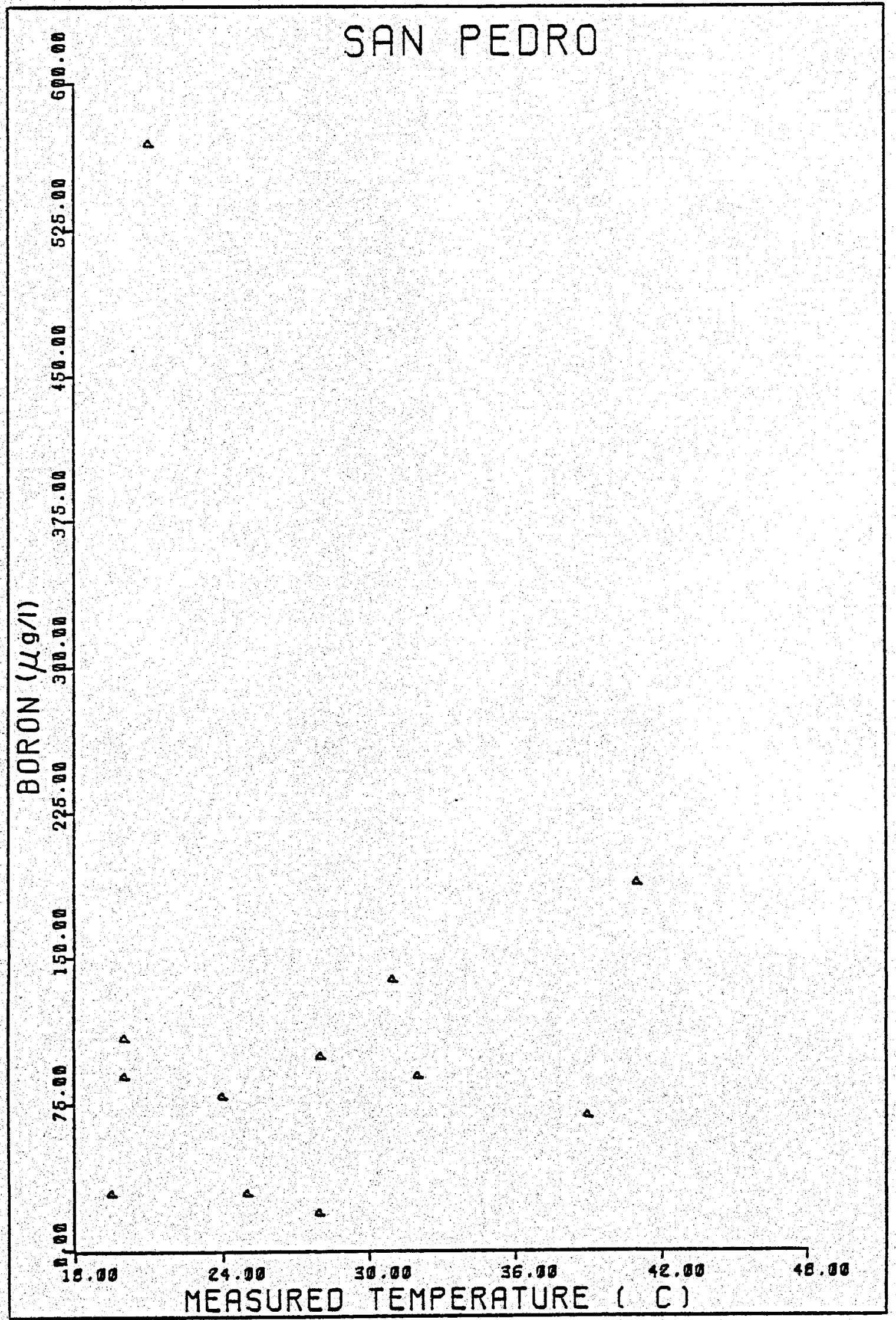

Figure 20. San Pedro: Computer plot of boron concentration $(\mu \mathrm{g} / 1)$ versus the measured well discharge temperature. 


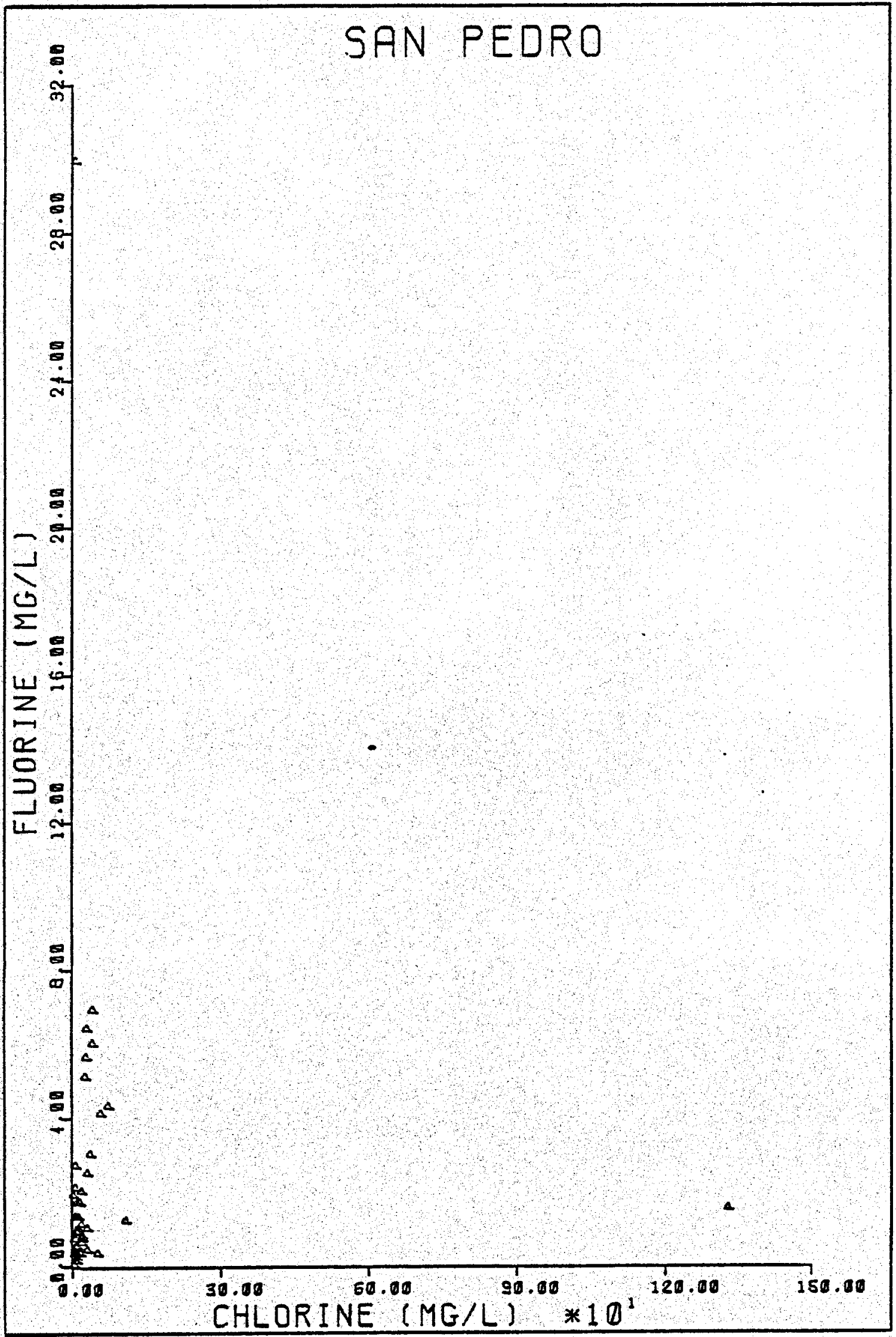

Figure 21. San Pedro: Computer plot of fluorine concentration (mg/1) versus chlorine concentration (mg/l). 
In an attempt to further delineate the structural geology and possible thermal areas, $80 \mathrm{~km}$ of reconnaissance mercury geochemical soil lines were run across the San pedro valley. These lines were situated perpendicular to the strike of the valley in an attempt to sample mercury vapor leaking upwards through the basin-fill material along buried fault zones. Also mercury anomalies are often associated with geothermal anomalies of igneous origin (Matlick, 1975). Figure 22 shows the location of the soil-sample lines and the values in parts per billion (ppb) mercury (Hg). Table 8 lists the values for the mercury samples. A background value of $65 \mathrm{ppb}$ Hg was determined by statistics. The writer considers values $2 \frac{1}{2}$ times background or greater to be ariomalous. SP-36 (160 ppb Hg) is the only anomalous value. This sample was taken in the proximity of weakly mineralized outcrops of precambrian and Paleozoic sediments.

It may be concluded from the results of the mercury sampling program that no fault structures were delineated by anomalous mercury values. possibly the faults along the sample lines were cemented closed by minerals precipitating from ground water or possibly there is an impermeable barrier in the basin fill material that is blocking the upward movement of mercury vapor or maybe there is no Hig vapor. 


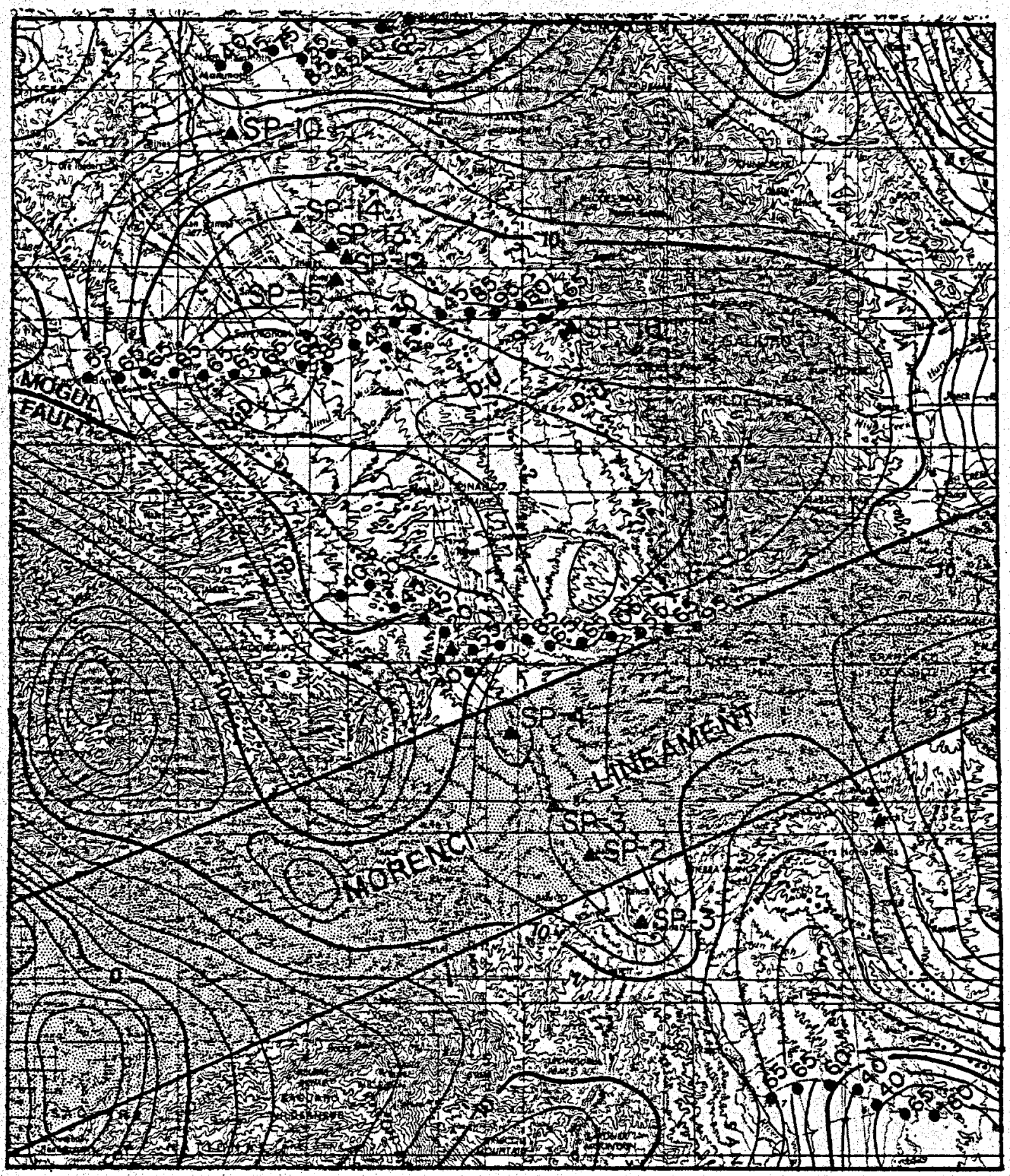

SAN PEORO:

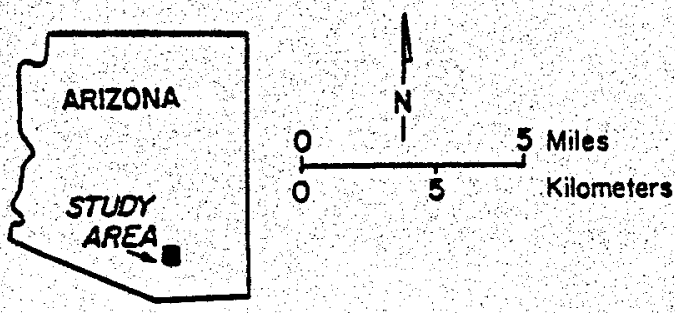

BASE MAP U.S.G.S TUCSON, $1,250,000$

- MERCURY CONTENT (pPb)

$\triangle$ WELL LOCATIONS

?...? Postulated and inferred faults

Bouguer Gravity

10 mgal contour

Figure 22

2 mgal contour 
TABLE 8

MERCURY GEOCHEMISTRY SOIL SAMPLES

\begin{tabular}{|c|c|c|c|c|c|}
\hline $\begin{array}{l}\text { Sample } \\
\text { Number }\end{array}$ & $\begin{array}{l}\mathrm{Hg} \\
\mathrm{ppb}\end{array}$ & $\begin{array}{l}\text { Sample } \\
\text { Number }\end{array}$ & $\begin{array}{l}\text { Hg } \\
\text { ppb }\end{array}$ & $\begin{array}{l}\text { Sample } \\
\text { Number }\end{array}$ & $\begin{array}{l}\mathrm{Hg} \\
\mathrm{ppb}\end{array}$ \\
\hline$S P-1$ & 65 & $S P-18$ & 65 & $S P-35$ & 40 \\
\hline$S P-2$ & 40 & $S P-19$ & 55 & $S P-36$ & 160 \\
\hline $\mathrm{SP}-3$ & 45 & $S P-20$ & 95 & $S P-37$ & 65 \\
\hline $\mathrm{SP}-4$ & 85 & SP -21 & 65 & $S P-38$ & 40 \\
\hline$S P-5$ & 55 & $\mathrm{SP}-22$ & 55 & SP-39 & 40 \\
\hline SP-6 & 75 & $S P-23$ & 105 & $S P-40$ & 60 \\
\hline$S P-7$ & 105 & $S P-24$ & 65 & $S P-41$ & 65 \\
\hline$S P-8$ & 40 & $S P-25$ & 65 & $S P-42$ & 65 \\
\hline $\mathrm{SP}-9$ & 45 & $S P-26$ & 85 & $S P-43$ & 65 \\
\hline$S P-10$ & 85 & $S P-27$ & 75 & $S P-44$ & 95 \\
\hline$S P-11$ & 85 & $S P-28$ & 55 & $S P-45$ & 80 \\
\hline$S P-12$ & 65 & $S P-29$ & 30 & $S P-46$ & 95 \\
\hline$S P-13$ & 65 & $S P-30$ & 75 & $S P-47$ & 85 \\
\hline$S P-14$ & 65 & $S P-31$ & 20 & $S P-48$ & 45 \\
\hline$S P-15$ & 65 & $S P-32$ & 45 & $S P-49$ & 45 \\
\hline$S P-16$ & 85 & $S P-33$ & 45 & $S P-50$ & 30 \\
\hline $\mathrm{SP}-17$ & 65 & $S P-34$ & 30 & & \\
\hline
\end{tabular}

Sample number with mercury values in parts per billion 


\section{CONCIUSIONS}

Three anomalous areas containing shallow-depth warm water have been located in the San Pedro study area: (1) the San Manuel-Mammoth area; (2) the A.C. Gruwell Ranch; (3) Hookers Hot Springs at the Muleshoe Ranch. The probable explanation for these warm water resources is as follows.

The Galiuro Mountains, the remains of a volcanic pile deposited along the axis of a large synform (Rehrig and Heidrick, 1976), are in all probability an area of recharge for the ground water system in the area. The meteoric water falling down upon the Galiuro Mountains percolates downward to great depths through fractures in the volcanic rocks, becomes heated, rises by convection along faults, encounters late Tertiary sedimentary units overlying these faults and migrates laterally through these sediments out into the basin. These warm waters are now near the surface because of erosion of the late Tertiary and quaternary sedimentary. units by the san pedro River. This type of phenomenon will readily explain the unreasonably high gradients encountered in some of the more shallow wells.

This 10w- to moderate-temperature geothermal resource may be utilized using current heat-pump technology for space heating and cooling, green house operations or in health spas. However, the size and production capabilities of the reservoir(s) has yet to be established. 


\section{REFERENCES}

Chapin, E.E., Chamberlin, R.M., Osburn, G.R. and white, D.W., 1978, Exploration framework of the Socorro geothermal area, New Mexico, in Chapen, C.E. and Elston, W.E., Special publication, New Mexico Geological Society, p. $115-129$.

Cooper, J.R., 1959, Some geologic features of the Dragoon quadrangle, Arizona, in Heindl, I.A., ed., Southern Arizona Guidebook II, Arizona Geological society, p. 139-145.

Drewes, H, and Thorman, C.H., 1978, Major geologic structures between Lordsburg, New Mexico and Douglas and Tucson, Arizona, in Callender, J.F., Wilt, J.C. and Clemons, R.E., eds., Iand of Cochise, Southeastern Arizona; New Mexico Geological society, Twenty-ninth Field Conference, p. 291-295.

Durning, W.P. and Davis, J.D., 1978, The root-zone characteristics of porphyry copper deposits, in Proceedings of the Porphyry Copper symposium, Arizoña Geological society Digest, v. 12, p. 81-89.

Fenneman, N.M., 1931, Physiography of western United States: McGraw-HiIl Book Company, Inc., p. 326-395.

Fournier, R. O. and Rowe, J.J., 1966, Estimation of underground temperatures from silica content of water from hot springs and wet steam wells: American Journal of science, v. 264, p. $685-697$.

Fournier, R.0. and Truesde11, A.H., 1973, An empirical Na-KCa geothermometer for natural waters: Geochemica et Cosmochemica Agta, v. 37, p. 1255-1275.

Gruwe11, A.C., 1981 , personal communication.

Heind1, I.A., 1963, Cenozolc geology in the Mammoth area, Pinal County, Arizona: U.S.G.S. Bulletin, 1141-E, p. 4I.

Krieger, M.H., 1974 , Generalized geology and structure of the winkelman 15-minute quadrangle and vicinity, pinal and Gila counties, Arizona: U.S.G.S. Journal of Research, $v \cdot 2$, no. $3, \mathrm{p} \cdot 311-321$.

Krieger, M.H., Cornwal1, H.R. and Banks, N.G., 1974, The Big Dome Formation and revised Tertiary stratigraphy in the Ray-San Manuel area, Arizona: U.S.G.S. Bulletin 1394A, p. 54-62. 
Iysonski, J.C., Aiken, C.I.V. and Sumner, J.S., 1981, Complete residual Bouguer gravity anomaly map, Tucson; scale 1:250,000, Bureau of Geology and Mineral Technology, open file.

Matlick, J.S., III, 1975, A new geothermal exploration method using mercury: Unpublished M.S. thesis, Arizona State University, $83 \mathrm{p}$.

Menges, C., 1981 , personal communication.

Montgomery, E.L., 1963, The geology and ground water investigation of the Tres Alamos dam site area of the san pedro River, Cochise County, Arizona: M.S, thesis, University of Arizona, 61 .

Rehrig, W.A. and Heidrick, T.L., 1976, Regional tectonic stress during Laramide and late Tertiary intrusive periods, Basin and Range province, Arizona, in Wilt, J.C. and Jenney, J.P., eds., Tectonic Digest, Arizona Geological Society Digest, $v, \mathrm{X}, \mathrm{p}, 205-228$.

Roeske, R.H. and Werre11, W.I., 1973, Hydrologic conditions in the san Pedro River valley, Arizona, 1971: Arizona water Commission, Bulletin 4 , Phoenix, $76 \mathrm{p}$.

Sauck, W.A. and Sumner, J.S., 1971, Residual aeromagnetic map of Arizona; scale 1:250,000, University of Arizona Press.

Scarborough, R.B., 1975, Chemistry and age of late cenozoic air-fall ash in southeastern Arizona: Unpublished M.S. thesis, University of Arizona, $107 \mathrm{p}$.

Scarborough, R.B. and Wilt, J.C., 1979, A study of uranium favorability of Cenozoic sedimentary rocks, Basin and Range province, Arizona, Part I: Bureau of Geology and Mineral Technology, Geological Survey Branch, Tucson, $101 \mathrm{p}$.

Schmitt, H.A., 1966, The porphyry copper deposits in their regional setting, in Titley, S.R. and Hicks, C.I., eds., Geology of the porphyry Copper Deposits Southwestern North America, University of Arizona Press, p. 17-34.

silver, L.T., 1978, Precambrian formations and Precambrian history in Cochise County, southeastern Arizona, in Callender, J.F., Wilt, J.C., and Clemons, R.E., eds., Land of Cochise, Southeastern Arizona; New Mexico Geological society, Twenty-ninth Field Conference, p. 157163. 
Swan, M.M., 1976, The Stockton Pass fault: an element of the Texas lineament: Unpublished M.S. thesis, University of Arizona, $119 \mathrm{p}$.

Titley, S.R., 1976, Evidence for a Mesozola linear tectonic pattern in southeastern Arizona, in Wilt, J.C. and Jenney, J.P., eds., Tectonic Digest, Arizona Geological Society Digest, $v . x, \mathrm{X} .71-102$.

WATSTORE, 1981, U.S. Geological Survey.

Witcher, J.C., 1981 , personal communication.

Witcher, J.C., 1981, Geothermal potential of the lower San Francisco River system: Bureau of Geology and Mineral Technology, Tucson, in press. 